ARTHUR ALONSO ALMEIDA SOUZA

Características físico-químicas e sensoriais da carne de bovinos Nelore (Bos taurus indicus) alimentados com diferentes fontes de lipídeos e de selênio 


\title{
Características físico-químicas e sensoriais da carne de bovinos Nelore (Bos taurus indicus) alimentados com diferentes fontes de lipídeos e de selênio
}

\author{
Dissertação apresentada ao \\ Programa de Pós-Graduação em \\ Nutrição e Produção Animal da \\ Faculdade de Medicina Veterinária e \\ Zootecnia da Universidade de São \\ Paulo para obtenção do Título de \\ Mestre em Medicina Veterinária
}

Departamento:

Nutrição e Produção Animal

Área de concentração:

Nutrição e Produção Animal

Orientador:

Prof. Dr. Marcos Veiga dos Santos 
Autorizo a reprodução parcial ou total desta obra, para fins acadêmicos, desde que citada a fonte.

DADOS INTERNACIONAIS DE CATALOGAÇÃO-NA-PUBLICAÇÃO

(Biblioteca Virginie Buff D’Ápice da Faculdade de Medicina Veterinária e Zootecnia da Universidade de São Paulo)

T.2055 Souza, Arthur Alonso Almeida

FMVZ Características físico-químicas e sensoriais da carne de bovinos Nelore (Bos taurus indicus) alimentados com diferentes fontes de lipídeos e de selênio / Arthur Alonso Almeida Souza. Pirassununga : A. A. A. Souza, 2008.

$$
71 \mathrm{f} \text { : : il. }
$$

Dissertação (mestrado) - Universidade de São Paulo. Faculdade de Medicina Veterinária e Zootecnia. Departamento de Nutrição e Produção Animal, 2008.

Programa de Pós-Graduação: Nutrição e Produção Animal. Área de concentração: Nutrição e Produção Animal.

Orientador: Prof. Dr. Marcos Veiga dos Santos.

1. Atributos de qualidade. 2. Carcaça. 3. Gado de corte. 4. Lipídeos. 5. Selênio. I. Título. 


\section{FACULDADE DE MEDICINA VETERINÁRIA E ZOOTECNIA} Comissão Bioética

\section{CERTIFICADO}

Certificamos que o Projeto intitulado "Efeitos da fonte de gordura e de selênio sobre a composição de ácidos graxos, ácido linoleico conjugado (CLA) e características da carne de bovinos nelore (Bos taurus indicus)", protocolo no883/2006, utilizando 54 (cinqüenta e quatro) bovinos, sob a responsabilidade do Prof. Dr. Marcos Veiga dos Santos, está de acordo com os princípios éticos de experimentação animal da Comissão de Bioética da Faculdade de Medicina Veterinária e Zootecnia da Universidade de São Paulo e foi aprovado "ad referendum".

(We certify that the Research "Fat source and selenium effects on fatty acids, conjugated linoleic acid (CLA) and meat characteristics on nelore steers (Bos taurus indicus)", protocol number 883/2006, utilizing 74 (seventy four) bovines, under the responsibility of Prof. Dr. Marcos Veiga dos Santos, agree with Ethical Principles in Animal Research adopted by Bioethic Commission of the Faculty of Veterinary Medicine and Zootechny of University of São Paulo and was approved "ad referendum", meeting).

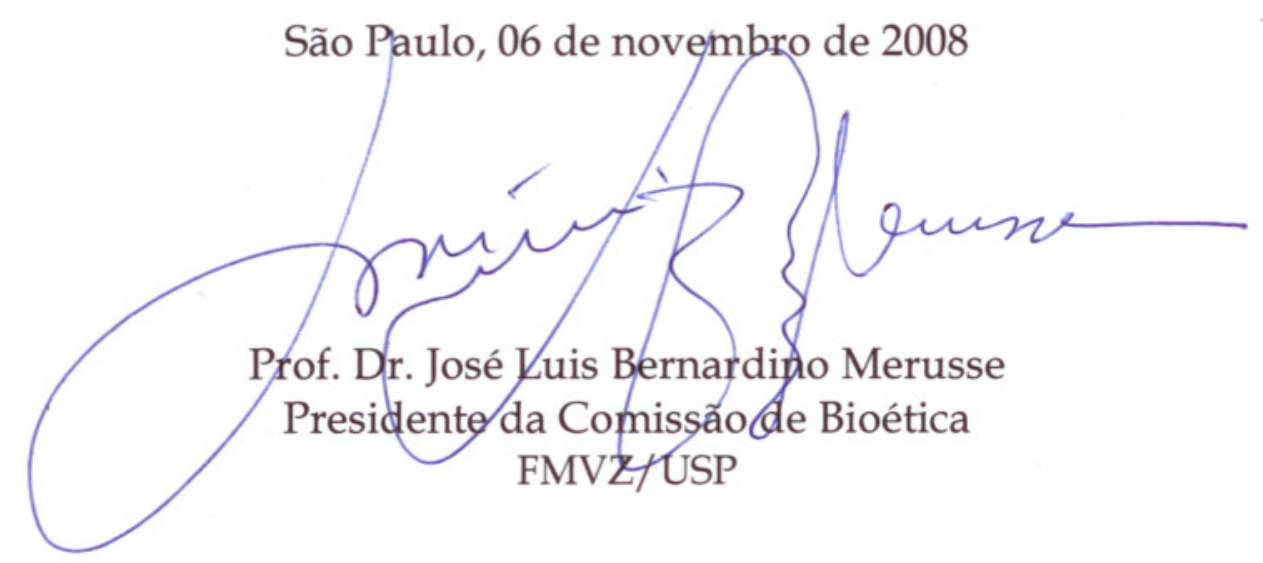




\section{FOLHA DE AVALIAÇÃO}

Nome: SOUZA, Arthur Alonso Almeida

Título: Características físico-químicas e sensoriais da carne de bovinos Nelore (Bos taurus indicus) alimentados com diferentes fontes de lipídeos e de selênio

Dissertação apresentada ao Programa de Pós-Graduação em Nutrição e Produção Animal da Faculdade de Medicina Veterinária e Zootecnia da Universidade de São Paulo para obtenção do Título de Mestre em Medicina Veterinária

Data:

Banca Examinadora:

Prof. Dr.

Assinatura:

Prof. Dr.

Assinatura:

Prof. Dr.

Assinatura:
Instituição:

Julgamento:

Instituição:

Julgamento:

Instituição:

Julgamento: 


\section{Dedico:}

"Aos meus pais, Esmeraldo e Daesy, pela sólida formação, pelo amor incondicional, inspiração, e acima de tudo exemplo de família e moral".

"A minha querida irmã Mônica, pela coragem, determinação, amizade, apoio e pelo presente mais querido que já recebemos na família, o Enzo".

"A minha futura esposa, Raquel, por me fazer acreditar todos os dias no amor, pelas alegrias, dedicação, por fazer parte de minha história e estar comigo em todos os momentos, realizando sonhos e planejando nosso futuro". 


\section{AGRADECIMENTOS}

Ao Prof. Dr. Marcos Veiga dos Santos, minha gratidão por aceitar a difícil tarefa de me orientar, mesmo conhecendo as dificuldades que iríamos encontrar. Agradeço pela constante cobrança para elaboração de um trabalho de qualidade $e$ pela compreensão das adversidades encontradas ao longo desta longa e árdua jornada.

Ao Prof. Dr. Paulo Leme, pelo apoio diário e proximidade do trabalho realizado.

A Angélica, idealizadora, e responsável incondicional pela conclusão deste trabalho. Minha eterna gratidão por aceitar meu ingresso no projeto e me orientar do início até a conclusão dessa jornada. Não tenho palavras para descrever minha gratidão.

À Gabriela e Rosana, agradeço sinceramente a contribuição imprescindível e entusiástica na realização do experimento.

Ao Prof. Antônio, Prof. Lucci Prof. Paneta e Prof Celso, por me servirem de exemplo de conduta digna no trabalho e na vida. Deixo registrada minha profunda admiração e respeito. Verdadeiras reservas morais dentro de nossa complexa profissão.

A todos os amigos da Pós-graduação, em especial ao Rodrigo (eterno Caixa), ao Gaucho, ao Valter, ao Bueno (Calabresa), ao Rinaldo, a Tereza e ao Brunão. Espero que nossa amizade perdure por muitos anos.

Ao Tubas, grande companheiro na vida e na profissão, agradeço por continuar me servindo de exemplo e estar sempre por perto para auxiliar nas decisões mais difíceis, esse trabalho também é seu.

À Fazenda da Aeronáutica, agradeço a autorização de afastamento parcial. Expresso agradecimento especial ao Cel De Souza, que permitiu o meu afastamento, ao Cap. Cavalcante, grande incentivador e principal responsável pelo apoio da instituição, a Viviane, pelo exemplo e apoio, a Luciana, Audeny e Soraia pela amizade e importante apoio moral. poucos!

À Universidade de São Paulo, pela realização de mais um sonho. Faltam

A todos que não citei, mas que de alguma forma são parte integrante e especial da minha vida. 
“Faça o que puder com o que tiver onde estiver"

Theodore Roosevelt 


\section{RESUMO}

SOUZA, A. A. A. Características físico-químicas e sensoriais da carne de bovinos Nelore (Bos taurus indicus) alimentados com diferentes fontes de lipídeos e de selênio. [Physical-chemical and sensorial characteristics of the Nellore bovine meat (Bos taurus indicus) fed with sources of fat and selenium]. 2008. 71 f. Dissertação (Mestrado em Medicina Veterinária) - Faculdade de Medicina Veterinária e Zootecnia, Universidade de São Paulo, Pirassununga, 2008.

Objetivou-se determinar os efeitos de dietas contendo três fontes de lipídeos (semente de girassol, caroço de algodão e soja em grão "in natura") e duas de selênio (orgânico ou inorgânico) sobre o desempenho animal, características de carcaça e qualidade da carne de bovinos da raça Nelore (Bos taurus indicus). Foram utilizados 54 machos, castrados, com idade média de 30 meses e com peso vivo médio de $458 \pm 39 \mathrm{~kg}$ no início do experimento. Os animais foram distribuídos em blocos, de acordo com o peso inicial, com delineamento em arranjo fatorial de tratamentos do tipo $3 \times 2$, cujos fatores de variação foram três fontes de lipídeos e duas fontes de selênio. Cada grupo de três animais foi alojado em uma baia por um período de 120 dias. As características de rendimento de carcaça, área de olho de lombo, espessura de gordura subcutânea, índice de marmorização, perdas totais ao cozimento e maciez objetiva não foram influenciadas pelo tipo de fontes de lipídeos ou de selênio na dieta. A inclusão de fonte orgânica de selênio resultou em maior concentração deste elemento no tecido muscular, quando comparada à fonte de selênio inorgânica. As fontes de lipídeos utilizadas na dieta influenciaram o atributo de suculência e sabor estranho da carne dos animais estudados enquanto a fonte de selênio influenciou apenas no atributo de sabor estranho.

Palavras-chave: Atributos de qualidade. Carcaça. Gado de corte. Lipídeos. Selênio. 


\begin{abstract}
SOUZA, A. A. A. Physical-chemical and sensorial characteristics of the Nellore bovine meat (Bos taurus indicus) fed with sources of fat and selenium. [Características físico-químicas e sensoriais da carne de bovinos Nelore (Bos taurus indicus) alimentados com diferentes fontes de lipídeos e de selênio]. 2008. $71 \mathrm{f}$. Dissertação (Mestrado em Medicina Veterinária) - Faculdade de Medicina Veterinária e Zootecnia, Universidade de São Paulo, Pirassununga, 2008.
\end{abstract}

This study was carried out to determine the effects of the inclusion of three sources of fat (sunflower seed, whole cottonseed and raw soybean ) and two sources of selenium (organic or inorganic) in the diets fed to Nellore cattle (Bos taurus indicus) on the animal performance and carcass and meat quality characteristics. Fifty-four bovine males, castrated, with an average age of 30 months and $458 \pm 39 \mathrm{~kg}$ at the beginning of the experiment were distributed, according to initial weight, in blocks with a 3x2 factorial arrangement: three sources of lipids and two sources of selenium. The animals were housed in stalls, three per pen, during 120 days. Carcass characteristics (carcass yield, the rib eye area, fat thickness, marbling index and shear force) were not influenced by the fat or selenium sources in the diet. The inclusion of organic source of selenium resulted in higher concentration in the muscle, compared to the inorganic source. The fat source used in diet influenced the attribute of juiciness and strange flavor of the animal's meat studied, however the selenium source influenced only the attribute of taste.

Key Words: Beef cattle. Carcass. Lipids. Quality attributes. Selenium. 


\section{LISTA DE TABELAS}

Tabela 1 - Proporção de ingredientes e composição bromatológica das dietas distribuídas por fontes de lipídeos em \% da matéria seca.

Tabela 2 - Peso vivo final (PVF), ganho médio diário (GMD), matéria seca ingerida (MSI), e conversão alimentar (CA) em função das fontes de lipídeos fornecidas na dieta

Tabela 3 - Peso vivo final (PVF), ganho médio diário (GMD), matéria seca ingerida (MSI), e conversão alimentar (CA) em função das fontes de selênio fornecida na dieta

Tabela 4 - Características de carcaça, em função das fontes de lipídeos fornecidas na dieta

Tabela 5 - Extrato Etéreo na carcaça, em função das fontes de lipídeos fornecidas na dieta

Tabela 6 - Características de carcaça em função das fontes de Se fornecidas na dieta

Tabela 7 - Extrato Estéreo da carcaça em função das fontes de Se fornecidas na dieta 


\section{LISTA DE ABREVIAÇÕES}

$A G I$ - ácidos graxos insaturados;

AGS - ácidos graxos saturados;

AOL - área de olho de lombo;

CA - caroço de algodão;

CA - conversão alimentar;

CANITO - 16,19\% de caroço de algodão + 0,3 mg de Selênio inorgânico;

CAPLEX - 16,19\% de caroço de algodão + 0,3 mg de Selênio orgânico;

CMS - consumo de matéria seca;

EA - eficiência alimentar;

EE - extrato etéreo;

EGS - espessura de gordura subcutânea;

FC - força de cisalhamento;

FDN - fibra em detergente neutro;

GINITO - 10,38\% de semente de girassol + 0,3 mg de Selênio inorgânico;

GIPLEX - 10,38\% de semente de girassol + 0,3 mg de Selênio orgânico;

GMD - ganho de peso médio diário;

IM - índice de marmorização;

IMS - ingestão de matéria seca;

$\mathrm{MO}$ - matéria original;

MS - matéria seca;

PAC - perda de água no cozimento;

PB - proteína bruta;

PCF - peso da carcaça fria;

$P C Q$ - peso da carcaça quente;

$\mathrm{PF}$ - peso do fígado;

$P G$ - peso da gordura;

$P V F$ - peso vivo final;

$\mathrm{RC}$ - rendimento de carcaça;

RCF - rendimento de carcaça fria;

$R C Q$ - rendimento de carcaça quente;

SeCys - selenocisteína; 
SeM - selenometionina;

SEL-PLEX ${ }^{\circledR}$ - produto comercial de selênio orgânico (Alltech, Kentucky - EUA)

SONITO - 13,71\% de soja grão + 0,3 mg de Selênio inorgânico;

SOPLEX - 13,71\% de soja grão + 0,3 mg de Selênio orgânico; 


\section{SUMÁRIO}

1 INTRODUÇÃO

2 REVISÃO DE LITERATURA

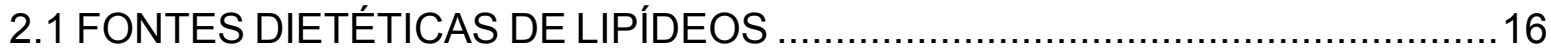

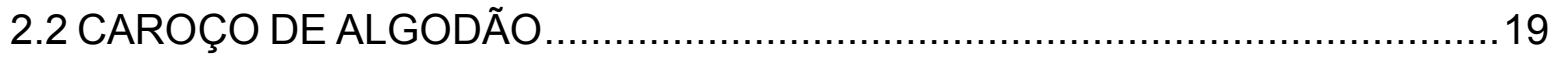

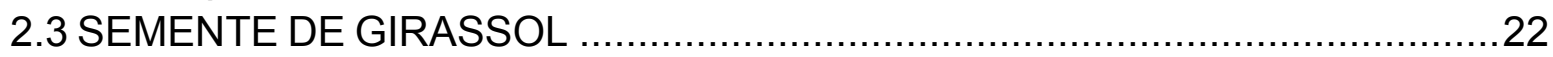

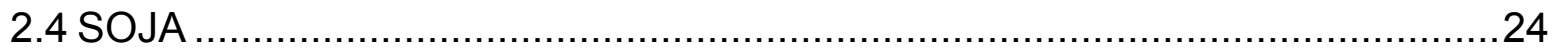

2.5 DESEMPENHO E CARACTERÍSTICAS DE CARCAÇA DE BOVINOS DE CORTE

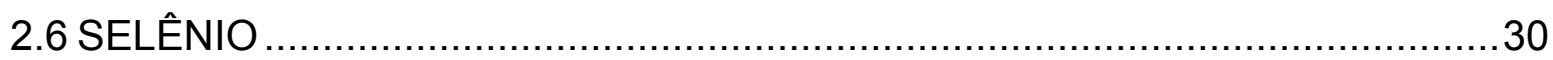

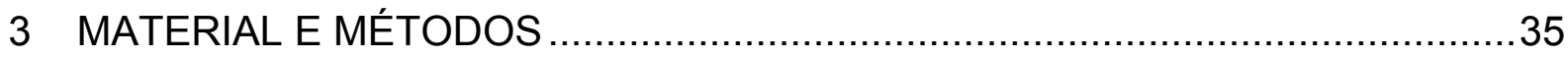

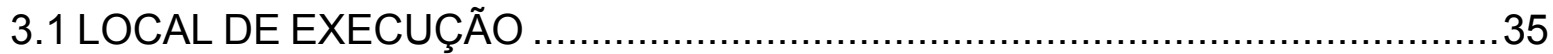

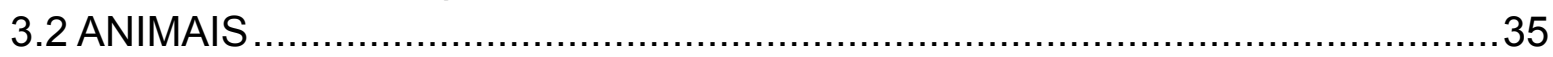

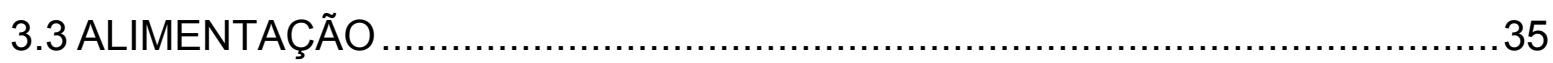

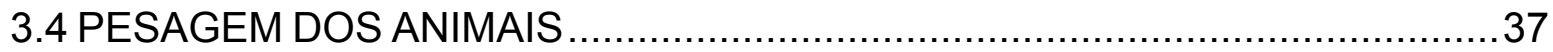

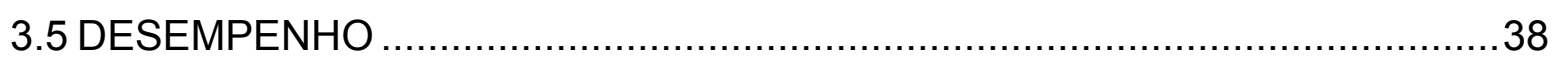

3.6 ABATE DOS ANIMAIS E RENDIMENTO DE CARCAÇA ................................38

3.7 CARACTERÍSTICAS FÍSICO-QUÍMICAS DA CARNE FRESCA E MATURADA

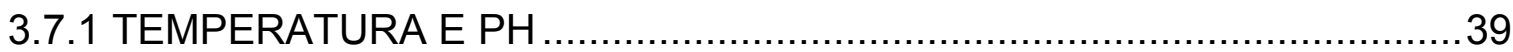

3.7.2 ÁREA DE OLHO DE LOMBO, ESPESSURA DE GORDURA

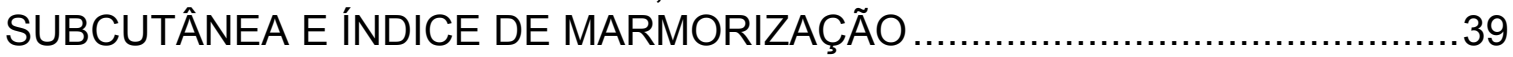

3.7.3 ANALISE DE MACIEZ OBJETIVA ...............................................40

3.7.4 ANÁLISE DE MACIEZ SUBJETIVA (SENSORIAL) ............................40

3.7.5 ANÁLISES DE COLESTEROL ....................................................... 42

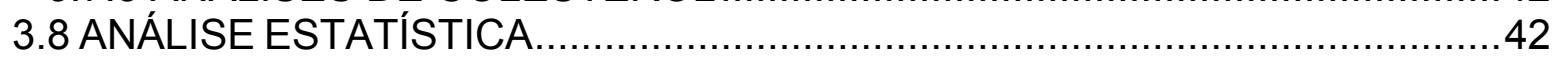

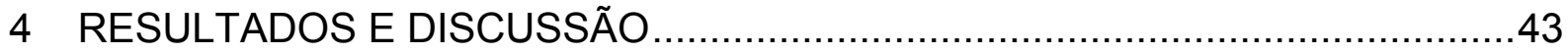

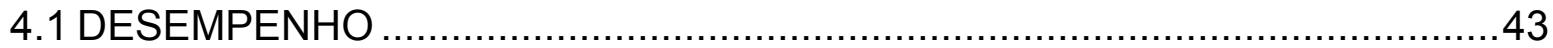

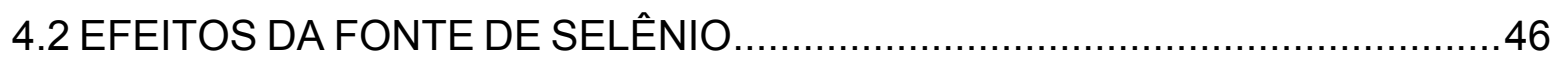

4.3 CARACTERÍSTICAS DE CARCAÇA E DA CARNE .......................................

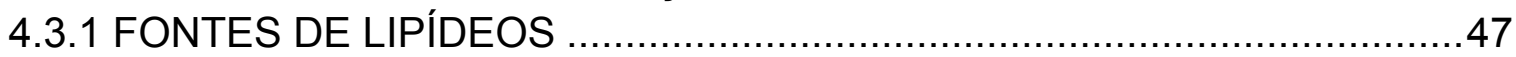

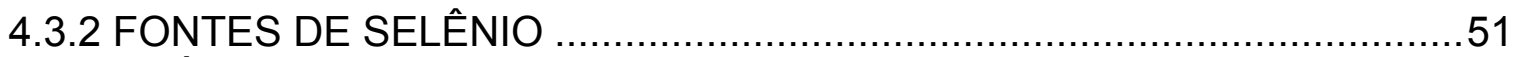

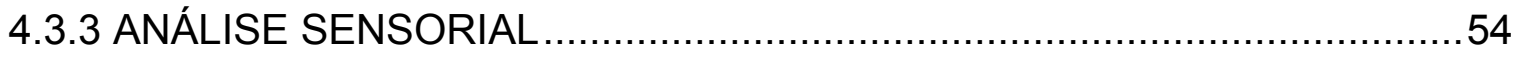

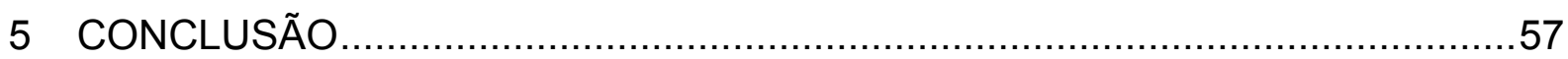

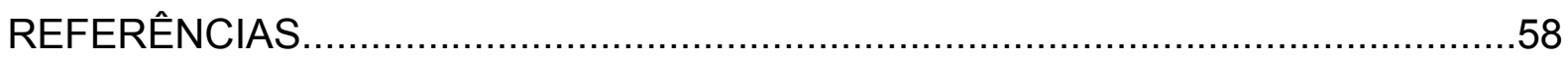

ANEXO 


\section{INTRODUÇÃO}

A gordura tem sido abolida das dietas humanas, responsabilizada erroneamente pelo excesso de colesterol e doenças cardiovasculares, num processo que desconsidera o valor nutricional desse elemento essencial para o funcionamento do organismo. O colesterol e outras gorduras são componentes essenciais das membranas das células, das quais dependem processos de nutrição, resposta imunológica, condução de estímulos por meio de neurônios, envelhecimento e apoptose das células (TAUBES, 2001).

Óleos vegetais, em geral, não são amplamente utilizados como suplementos de dietas, devido à elevada quantidade de ácidos graxos polinsaturados, que podem ser tóxicos às bactérias ruminais. Uma alternativa consiste no fornecimento de sementes com alto teor de lipídeo, que permitem que o óleo se torne gradualmente disponível no rúmen, sem efeitos adversos para o crescimento microbiano (MADRON et al., 2002).

O tipo de dieta altera algumas características qualitativas da carne produzida, tais como quantidade de gordura intramuscular (marmorização), sabor, aroma e maciez, além da possibilidade de modificar a composição da gordura da carne. Existe correlação positiva entre marmorização e maciez da carne, sendo que a marmorização influencia o sabor e suculência (MAY et al., 1992; PARDI et al., 1995).

Além disso, o aumento do conteúdo de ácidos graxos insaturados presentes em sementes oleaginosas contribui para redução da vida de prateleira das carnes, com conseqüente produção de sabor e aromas indesejáveis. Esses ácidos, muito suscetíveis à oxidação, durante o cozimento, relacionam-se negativamente com o sabor, em análises sensoriais (DUCKETT, 1993).

Os ácidos graxos insaturados da membrana celular são suscetíveis ao ataque dos radicais livres devido a suas estruturas químicas, que permitem a retirada de átomos de hidrogênio de um dos grupos $-\mathrm{CH}_{2}$ da cadeia carbônica e a conseqüente formação de um radical livre, iniciando-se o processo de peroxidação lipídica (COMBS et al., 2001). Este processo pode resultar ainda em rancidez da carne, deterioração da cor, textura e sabor da carne fresca, congelada e cozida (LIU et al., 1995). 
O selênio (Se) pode prevenir a degradação peroxidativa de gorduras das células animais e a formação de radicais livres. Além disso, Surai et al. (1999), relataram que apesar do fornecimento de níveis adequados de antioxidantes (vitamina E), a deficiência de selênio acelerou o processo de peroxidação lipídica, levando aos danos severos nos tecidos celulares.

Objetivou-se avaliar os efeitos da adição de semente de girassol, caroço de algodão ou soja em grão "in natura" e de selênio orgânico ou inorgânico em dietas para bovinos da raça Nelore (Bos taurus indicus) sobre o desempenho, características de carcaça e qualidade da carne destes animais. 


\section{REVISÃO DE LITERATURA}

\subsection{FONTES DIETÉTICAS DE LIPÍDEOS}

A inclusão de gordura na dieta de ruminantes em terminação pode levar a efeitos benéficos diretos, como o aumento da densidade energética da dieta, ou indiretos, como a redução na produção de metano, com reflexos no aumento da eficiência alimentar e melhoria no desempenho animal (ZINN; PLASCENCIA, 1996). Neste sentido, explicar a variabilidade na resposta do ganho de peso em bovinos suplementados com dietas contendo gorduras tem direcionado a atenção de pesquisadores (ZINN, 1989).

Os lipídeos ou gorduras são compostos de ácidos graxos pertencentes em grande número a dois grupos, o dos ácidos graxos insaturados e saturados. $O$ estado de saturação é uma importante característica química, bem como nutricional. Quimicamente, os ácidos graxos saturados são aqueles sem duplas ligações na sua estrutura e os insaturados são aqueles com duplas ligações (LEHNINGER, 2000)

Segundo Chilliard (1993), a gordura é utilizada na ração de ruminantes por três razões: 1) o alto valor calórico, que pode ser útil para sobrepor limitações nos suprimentos energéticos em ruminantes de alta produção; 2) para manipular a digestão e absorção de nutrientes, como por exemplo, a gordura pode limitar a acidose ruminal e reduzir o conteúdo de gordura do leite resultantes do alto teor de carboidratos e baixa fibra das rações, sendo que podem ainda alterar a proporção de determinados ácidos graxos na carne e gordura do leite, de acordo com as necessidades da indústria alimentar para consumo humano; 3) alguns lipídeos de origem vegetal ou animal apresentam baixos preços dependendo da estação do ano.

A gordura constitui a fração mais energética dos alimentos e, como os carboidratos, é composta de carbono $(C)$, hidrogênio $(H)$, e oxigênio $(O)$, sendo a proporção dos dois primeiros, bem maior nas gorduras que nos carboidratos (SILVA, 1998). 
Os lipídeos (óleo ou gordura) têm sido utilizados para aumentar a densidade energética das dietas, uma vez que têm 2,25 vezes mais conteúdo energético que os carboidratos (REDDY et al., 1994), e por esse motivo, a utilização de fontes de lipídeos de origem vegetal, como óleos vegetais e sementes oleaginosas e de gordura animal, como sebo, é uma das alternativas empregadas para aumentar a densidade energética da dieta.

A digestão de gorduras inicia-se no rúmen. Os lipídeos, ao chegarem ao rúmen, são transformados pelas bactérias lipolíticas, ocorrendo inicialmente hidrólise em ácidos graxos e glicerol. Logo após, sofrem saturação ou biohidrogenação pelas bactérias biohidrogenadoras (PALMQUIST, 2001).

Depois que os lipídeos são metabolizados no rúmen, ocorre pouca digestão suplementar de gordura nesta câmara gástrica; os ácidos graxos seguem para o intestino delgado, ou seja, as gorduras se combinam com partículas dos alimentos e passam do abomaso para intestino, no qual são misturadas com ácido pancreático, bile e enzimas digestivas para serem absorvidas (TEIXEIRA; HUBER, 1989).

Entretanto, existem efeitos negativos da inclusão de lipídeos às dietas principalmente com relação à queda da digestibilidade das frações fibrosas (HENDERSON, 1973; DEVENDRA; LEWIS,1974; VARGAS et al., 2002). A adição de lipídeos à dieta de ruminantes pode interromper a fermentação ruminal, com redução da degradação de carboidratos estruturais em $50 \%$ ou mais pela adição de até $10 \%$ de gordura. Se por um lado dietas ricas em energia podem melhorar a eficiência, a qualidade da carcaça e da carne de bovinos, os níveis de gordura nas rações para ruminantes superiores a $5 \%$ tendem a reduzir o consumo de alimentos dos animais (NRC, 1984)

As teorias que explicam o efeito negativo da adição de lipídeos à dieta de ruminantes sobre a digestibilidade da fibra são: cobertura física da fibra no rúmen, impedindo o ataque microbiano e a ação enzimática; efeito direto dos ácidos graxos sobre determinados microrganismos ruminais (citotoxidade), com alterações na fosforilação oxidativa ocorrida na membrana celular e a redução da disponibilidade de cálcio necessário às funções microbianas, modificando a microbiota ligada à digestão da celulose (JENKINS, 1993). 
Visando diminuir o efeito negativo da gordura sobre o ambiente ruminal e conseqüentemente sobre a degradabilidade da fibra, podem-se utilizar gorduras protegidas da digestão ruminal. As mais comuns são os sais de cálcio de ácidos graxos ou sementes de oleaginosas (MULLER et al., 2005).

French et al. (2000) afirmaram que existem evidências de que as características das dietas fornecidas aos animais podem alterar a composição de lipídeos da carcaça de bovinos.

Muller et al. (2005), avaliaram o efeito da suplementação sobre o desempenho e as características da carcaça de novilhas terminadas em confinamento. Os autores utilizaram 23 novilhas cruzadas $(1 / 2$ Nelores e $1 / 2$ Red Angus), com idade média de 20 meses e peso vivo médio inicial de $351 \mathrm{~kg}$, recebendo suplementação com semente de linho, suplementação com gordura protegida com sais de cálcio e dieta controle sem adição de fontes de lipídeos. De acordo com os resultados encontrados, as fontes de lipídeos testadas podem ser utilizadas sem causar queda no desempenho e nas características de carcaça de novilhas confinadas.

Segundo Rabello et al. (1996), entre as fontes de lipídeos mais utilizadas no Brasil, podem ser citadas àquelas de origem vegetal, tais como as sementes de oleaginosas (algodão, girassol e soja). Este tipo de semente apresenta, durante a digestão, uma liberação lenta de gordura, o que ocasiona pequeno efeito na função ruminal (PALMQUIST; JENKINS, 1980; DEPETERS et al., 1985; COPPOCK; WILKS, 1991; KNAPP et al., 1991). A extrusão da semente libera parte do óleo de maneira que a velocidade de exposição dos microrganismos ao óleo pode ser suficiente para interferir no metabolismo.

Além disso, sementes oleaginosas são importantes fontes de lipídeos, pois além de fornecerem energia, apresentam também elevado teor de proteína bruta (PB) e vantagem de baixo custo em certas épocas do ano (URANO, 2005). 


\subsection{CAROÇO DE ALGODÃO}

O caroço de algodão é um subproduto da indústria e tem sido utilizado em dietas de ruminantes principalmente na tentativa de diminuir o custo com alimentação (EZEQUIEL, 2001). Sua principal vantagem está no seu alto teor de energia e no seu considerável teor de proteína e fibra (ENSMINGER et al., 1990). A utilização desta semente na alimentação de ruminantes tem despertado grande interesse principalmente por se tratar de uma importante fonte energético-protéica suplementar às forragens, além de representar reflexos positivos nos índices de produtividade dos rebanhos e contribuição para a qualidade dos produtos de origem animal, quanto à formulação de dietas humanas mais saudáveis (ROGÉRIO et al., 2004).

O caroço de algodão é composto em média por $19,3 \%$ de extrato etéreo $(E E)$, $23,5 \%$ de proteína bruta (PB), $77 \%$ de nutrientes digestíveis totais (NDT) e $50,3 \%$ de fibra em detergente neutro (FDN) (NRC, 2001). Além disso, é reconhecidamente um alimento de qualidade para bovinos e usualmente utilizado em substituição de cereais presentes na dieta dos animais.

O principal limitante nutricional do caroço de algodão é o pigmento gossipol, presente principalmente na semente integral. A maioria das sementes de algodão possui teores de gossipol entre $0,6 \%$ e $2,0 \%$, podendo a concentração diferir em relação às espécies e variedades existentes de sementes de algodão (BENBOUZA et al., 2002).

O gossipol $\left(\mathrm{C}_{30} \mathrm{H}_{30} \mathrm{O}_{8}\right)$ é um composto polifenólico de cor amarela capaz de proteger a planta contra danos provocados por insetos. Possui ação antioxidante e antipolimerizante e é produzido em glândulas localizadas nas raízes, folhas, hastes e sementes da planta do algodão. Porém, este pode representar um fator limitante em sua utilização, causando intoxicação em animais (WILKS et al., 1991), embora em menor nível para os ruminantes (ARIELI, 1998).

As manifestações de intoxicação nos casos leves resultam em diminuição do apetite e retardamento do desenvolvimento de necrospermia em machos. Nos casos mais graves, ocorre prostração, inflamação da mucosa do abomaso, urina com 
coloração vermelha/marrom, dificuldade respiratórias, distúrbios circulatórios e espasmos, ocorrendo à morte muitas vezes de forma inesperada (GARCIA, 2005).

Gray et al. (1993) estudaram o fornecimento de dietas contendo até $30 \%$ da MS de caroço de algodão, por 62 dias, para fêmeas bovinas de corte e observaram que o consumo de matéria seca e a condição corporal dos animais não foram afetados pela quantidade de gossipol ingerido.

Não foi observado nenhum sinal de intoxicação em vacas leiteiras alimentadas com dietas contendo caroço de algodão inteiro em porcentagens variando de $30 \%$ (HAWKINS et al., 1985), 31\% (SMITH et al., 1980) até 55\% da MS no concentrando (COPPOCK et al., 1987).

O caroço de algodão possui uma grande vantagem, assim como outras sementes oleaginosas, pois promove, durante a digestão ruminal, lenta liberação de sua fração lipídica e permite assim atuação dos microrganismos ruminais na hidrogenação das duplas ligações dos ácidos graxos insaturados, impedindo o efeito inibidor da gordura sobre a digestibilidade da fibra (WILKS et al., 1991). Em experimentos realizados por Rogério et al. (2004), não houve efeito negativo da inclusão do caroço de algodão sobre o consumo de matéria seca e de matéria orgânica.

De acordo com Brosh et al. (1989), usando o caroço de algodão como fonte energética e protéica, a inclusão desta semente na alimentação foi vantajosa até o nível de $120 \mathrm{~g} / \mathrm{kg}$ de matéria seca. Por outro lado, valores superiores prejudicaram a atividade da flora ruminal pelo excesso de óleo.

Em estudos conduzidos por Havartine et al. (2002), com avaliação da efetividade da fibra do caroço de algodão integral, em substituição à silagem de alfafa na proporção de $0 \%, 10 \%$ e $15 \%$, concluiu-se que a fibra detergente neutro (FDN) do caroço de algodão apresentou aproximadamente $84 \%$ da efetividade da FDN da silagem de alfafa, e que o uso de até $15 \%$ de caroço de algodão na dieta manteve a atividade ruminal em dietas com baixo conteúdo de FDN proveniente das forragens, demonstrando que sua fibra é tão efetiva no rúmen quanto a de forragens.

Posteriormente, Valinote (2005) utilizou novilhos Nelore com cânulas ruminais e observou que o caroço de algodão e o sal de cálcio de ácidos graxos, oferecidos como fontes lipídicas, não prejudicaram a atividade ruminal em dietas contendo alta proporção de concentrado. 
Rogério et al. (2004) estudaram a inclusão de caroço de algodão na dieta de ovinos (0 a 45\%) do total fornecido. A inclusão do caroço de algodão em $24 \%$ do total das dietas apresentou os melhores resultados quanto ao consumo.

Aferri et al. (2005) avaliaram o desempenho animal, as características da carcaça e a maciez da carne de 36 novilhos mestiços com média de 14 meses de idade e aproximadamente $320 \mathrm{~kg}$ de peso vivo, confinados, e recebendo dietas contendo $81 \%$ de concentrado e $21 \%$ de caroço de algodão. Os autores concluíram que a inclusão de $21 \%$ de caroço de algodão pode ser utilizada em rações para confinamento, sem prejudicar o rendimento de carcaça, dos cortes cárneos, medidas de área de olho de lombo e a espessura de gordura subcutânea na carcaça.

Brosh et al. (1989), utilizando caroço de algodão na proporção de $0 \%, 12 \%$, $18 \%$ e $24 \%$ da dieta de bovinos em confinamento, concluíram que a inclusão deste alimento acima de $12 \%$ na ração acarretou diminuição no ganho de peso, sem alterar o consumo de MS, sendo que o ganho de peso foi significativamente menor para os níveis de inclusão superiores a $18 \%$.

Prado et al. (1995) avaliaram o desempenho, o consumo, a conversão alimentar e as características de carcaça de novilhos Nelore de 2,5 anos confinados por um período de 105 dias, alimentados com cana-de-açúcar ou capim elefante e com inclusão de 15 ou $30 \%$ de caroço integral de algodão em rações à base de bagaço auto-hidrolisado de cana-de-açúcar. Os autores afirmaram que estes ingredientes nestas proporções não influenciaram nenhuma das características avaliadas.

Segundo Page et al. (1997), bovinos da raça Brangus confinados com dietas contendo $30 \%$ de caroço de algodão apresentaram maior peso vivo e maior quantidade de gordura renal, pélvica e cardíaca do que os animais do grupo controle, sem diferença entre os tratamentos para a espessura de gordura subcutânea.

Huerta-Leidenz et al. (1991), forneceram dietas contendo caroço de algodão incluídos em níveis de 0\%, 15\% e 30\% para bovinos cruzados Hereford-Angus terminados por um período de 56 dias de confinamento. Os autores não encontraram diferenças quanto ao ganho médio diário de peso, conversão alimentar e espessura de gordura subcutânea nos três tratamentos. Entretanto, ocorreram reduções significativas do peso da carcaça e da área de olho de lombo, com o nível de inclusão de $30 \%$. 
Lubis et al. (1990) compararam o ganho de peso de vacas em lactação recebendo dieta controle sem lipídeo e outras contendo diferentes níveis de caroço de algodão. Os autores não encontraram diferença para a característica estudada entre o controle e a dieta com $15 \%$ de caroço de algodão. Porém, foi observada redução na ingestão de matéria seca dos animais que estavam recebendo a dieta contendo caroço de algodão.

Cunha (2008) avaliou os efeitos de dietas com diferentes níveis de caroço de algodão integral (zero; $20 \%$; $30 \%$ e $40 \%$ ) na matéria seca sobre o desempenho, em 24 cordeiros da raça Santa Inês. A inclusão do caroço de algodão em todos os níveis utilizados pelo autor, não alterou o consumo de MS, mas deprimiu o ganho de peso e diminuiu a conversão alimentar.

\subsection{SEMENTE DE GIRASSOL}

De acordo com Cavasin (2001), o girassol é considerado uma excelente fonte de lipídeo. Segundo Popinigis (1985), sementes de girassol (Helianthus annuus L.), possuem em média $19 \%$ de carboidratos, $26 \%$ de lipídeos e $17 \%$ de proteínas.

No Brasil, a cultura do girassol encontra amplas condições de desenvolvimento devido às condições edáficas e climáticas favoráveis do Norte até o Sul do país. 0 plantio em maior escala encontra-se nos estados da Região Sul e no Sudeste de Goiás, em razão devido à localização das indústrias de extração de óleo (SILVA, 1990; DALLAGNOL, 2005)

O óleo de girassol apresenta alta concentração de ácidos graxos insaturados (AGI), principalmente o linoléico e o oléico, baixo teor de ácido linolênico e, em torno de $15 \%$ de ácidos graxos saturados, principalmente o palmítico e o esteárico. $O$ elevado teor de AGI torna o óleo de girassol adequado, do ponto de vista nutricional, já o baixo teor de ácido linolênico favorece a estocagem da semente, mantendo a sua qualidade (BRASIL, 1999).

A proteína de girassol contém alto teor de aminoácidos sulfurados e é sem dúvida, uma fonte de proteínas de alta qualidade para ruminantes. O farelo de girassol contém maior teor de proteína que os farelos de outras oleaginosas, tais como a soja, algodão. A farinha desengordurada e os concentrados e isolados 
protéicos de girassol possuem um considerável potencial nutricional, devido à ausência de fatores tóxicos (MANDARINO, 1992).

A semente de girassol destaca-se por suas características funcionais. A proteína desta semente oleaginosa apresenta propriedades que lhe confere grandes vantagens em sua utilização, como solubilidade, emulsificação, formação e estabilidade de espuma, formação de gel, absorção de água e de gordura (DAMODARAN, 1994).

Fornecendo dietas contendo grão de girassol integral, torta de girassol, grão de soja integral e parcialmente desengordurado, farelo de soja, farelo de gérmen de milho desengordurado e concentrado comercial com 36\% de PB, Beran et al. (2007), determinaram a digestibilidade de componentes nutricionais não-degradados no rúmen e verificou que a digestibilidade total da MS e MO do grão integral de girassol foi maior para todas as taxas de passagem, que a da torta de girassol obtida com uma prensagem. Esses resultados indicam que o teor de óleo não teve efeito negativo na digestão destes componentes nutritivos. O grão de girassol apresentou maior digestibilidade se comparado ao grão de soja integral e ao grão de soja parcialmente desengordurado. Isto pode ser devido provavelmente à alta degradabilidade efetiva da PB desses alimentos a essa mesma taxa de passagem.

Mir et al. (2008), avaliaram os efeitos do fornecimento de dietas contendo sementes de girassol (SG) e fosfato de tilosina (FT) sobre os fatores de produção e características de carcaça de 48 novilhos mestiços com peso corpóreo inicial médio de $373 \pm 8,4 \mathrm{~kg}$. Os novilhos foram alimentados individualmente, com uma dieta controle, e outra contendo $15 \%$ da dieta de semente de girassol. Além disso, metade dos animais, foi alimentada com dieta contendo fosfato de tilosina em $11 \mathrm{mg} / \mathrm{kg}$ de MS. Uma redução no CMS foi observada de 10,1 $\pm 0,4 \mathrm{~kg} / \mathrm{d}$ nos alimentados com a dieta controle para 8,9 \pm 0,3 e 8,6 \pm 0,3 kg/d nos que consumiram SG e SG + FT, respectivamente. Foi observado maior GMD para novilhos alimentados com a dieta controle 1, $4 \mathrm{~kg} / \mathrm{d}$, do que naqueles alimentados com dietas SG 1,1 kg/d, ou SG + FT sendo $1,2 \mathrm{~kg} / \mathrm{d}$. O rendimento de carne magra (\%) de novilhos alimentados com SG foi maior do que aqueles alimentados com dietas controle.

Gibb et al. (2004), avaliaram o valor de sementes de girassol (SG) em dietas de acabamento para 60 novilhos com peso inicial de $479 \pm 45 \mathrm{~kg}$. Os animais foram alimentados com uma dieta controle e outras com substituição da silagem da dieta controle por $9 \%$ e $14 \%$ de SG grão, ou $9 \%$ e $14 \%$ SG laminada. Substituindo toda 
silagem por SG laminado, não houve alteração significativa no CMS e no GMD, enquanto que a substituição da silagem com SG laminado não teve qualquer efeito sobre o CMS e apenas um ligeiro aumento no GMD. Dessa forma, os autores concluíram que nenhum benefício da substituição de SG por grãos e forrageiras foi detectado.

Em um estudo com bezerros em crescimento alimentados com farelos de girassol, de soja ou de colza, Stake et al. (1973), não encontraram diferenças na digestibilidade, matéria seca ou proteína bruta das dietas experimentais, ou desempenho dos animais avaliados.

Alguns estudos com ruminantes, em fase de crescimento, e com vacas leiteiras indicaram que o valor nutricional do farelo de girassol é equivalente ao farelo de soja e ao farelo de algodão (RICHARDSON, 1981; VINCENT et al., 1990).

\subsection{SOJA}

A soja tem se destacado na alimentação animal como uma das leguminosas mais ricas, quando avaliadas as suas características nutricionais, podendo ser fornecida na forma de grãos, farelo de soja, rolão, silagem, massa verde e, ainda, como feno obtido do corte nas fases de desenvolvimento vegetativo, floração ou frutificação (GRIS, 2008).

A produção mundial de soja na safra 2005/2006 foi estimada em 218 milhões de toneladas. O Brasil ocupa a segunda posição na lista dos maiores produtores, contribuindo com cerca 53,41 milhões de toneladas, em uma área plantada de aproximadamente 22,22 milhões de hectares, com uma produtividade média de 2403 kg/ha (AGRIANUAL, 2007).

Entre as opções de alimentação com dietas ricas em lipídeos, o grão de soja destaca-se pela sua disponibilidade regional, pelo elevado teor de ácidos graxos insaturados e pela grande aceitação dos animais (PALMQUIST; MATTOS, 1978; PALMQUIST, 1991; RABELLO et al., 1996).

A soja grão é uma excelente fonte de proteína, e devido ao seu alto teor de lipídeos, consiste também em uma ótima fonte de energia. Dentre as sementes de 
oleaginosas, o grão de soja é o mais empregado nos países desenvolvidos, com o objetivo de suprir lipídeos em rações de vacas de alta produção (RUEGSEGGER; SCHULTZ, 1985).

Segundo NRC (1985), grãos de soja (GS) contêm cerca de 90\% de nutrientes digestíveis totais (NDT), valor superior ao encontrado nos grãos de milho. Possuem composição média de $19 \%$ de gordura e $39 \%$ de proteína bruta (STERN; ILLG, 1991) e apresentam 10\% mais energia líquida, por quilo, de matéria seca, que a soja na forma de farelo (NRC, 1988).

Entretanto, a soja possui alguns fatores antinutricionais, como inibidores de tripsina, hemaglutininas (lecitinas), ácido fítico, enzimas lipase e lipoxidase, estrógenos, fatores flatulentos e alergênicos (glicininas e conglicininas), usualmente inativados por aquecimento dos grãos (BUTOLO, 2002).

Moletta (1999), fornecendo silagem de milho e concentrado contendo $20 \%$ de grão de soja, ou caroço de algodão para novilhos mestiços Canchim, não observou diferença entre os tratamentos, quanto ao consumo diário de MS, rendimento de carcaça, conversão e eficiência alimentar.

Com o objetivo de investigar o efeito de diferentes fontes de lipídeos na dieta de vacas Jersey, Duarte et al. (2005) utilizaram oito vacas Jersey, distribuídas em dois quadrados Latinos $(4 \times 4)$, recebendo uma das seguintes dietas: concentrado sem gordura; concentrado com sebo bovino; concentrado com gordura protegida comercial (sais de cálcio + óleo de palma); ou concentrado com grão de soja. Os pesos vivos médios dos animais não diferiram entre os tratamentos o que possivelmente, segundo os autores, explica-se pelo fato de o consumo de MS também não ter diferido entre os tratamentos.

A forma de utilização mais comum da soja na alimentação animal, e particularmente, em bovinos de corte, é o farelo. Porém, alguns autores verificaram que características de desempenho de animais alimentados com soja grão e farelo de soja, são muito próximas ou semelhantes (PELEGRINI et al., 2000; PAULINO et al., 2002).

Paulino et al. (2002) avaliaram 12 novilhos mestiços Holandês-Zebu com idade e peso médios iniciais de 24 meses e $361 \mathrm{~kg}$, respectivamente, recebendo dietas contendo suplementos múltiplos, a fim de avaliar soja grão e caroço de algodão inteiro, em relação a suplemento padrão de milho mais farelo de soja, durante a época seca. Os autores verificaram que o emprego de grão de soja, ou 
caroço de algodão em suplementos para terminação de bovinos em pastejo, durante a época seca, propiciou desempenho animal semelhante entre dietas fornecidas.

Milton et al. (1997) conduziram um experimento com 384 novilhos com peso médio inicial de $367 \mathrm{~kg}$, no intuito de comparar os farelos de soja e de girassol e suas combinações como fontes protéicas na alimentação de novilhos em fase de terminação sobre o desempenho animal e observaram que não houve diferença entre os tratamentos, sobre as características de consumo de matéria seca, ganho de peso diário e eficiência de ganho dos animais.

Coppock e Wilks (1991) afirmaram que a digestibilidade dos lipídeos de sementes oleaginosas não promove efeito negativo na ingestão, provavelmente em razão da lenta liberação dos lipídeos dos grãos, não superando, dessa forma, a capacidade de hidrogenação dos microrganismos ruminais. Tais afirmações podem ser evidenciadas por Fernandes (1987), que estudou o efeito da utilização da soja grão, crua e moída em dietas de vacas leiteiras de alta produção. Foram avaliados três níveis de inclusão da soja grão crua na dieta dos animais, $20 \%$ e $40 \%$ de inclusão no concentrado e concluiu-se que existe a possibilidade de inclusão de até $40 \%$ na dieta, sem qualquer efeito negativo no consumo.

Com o objetivo de avaliar a influência de teores crescentes de grão de soja (GS) em rações com alta proporção de concentrado para cordeiros Santa Inês, Urano (2005) utilizou rações isonitrogenadas contendo zero, 7\%, 14\% e $21 \%$ de GS na matéria seca, $O$ consumo de matéria seca $(1,1 ; 1,0 ; 0,9 ; 0,9 \mathrm{~kg} / \mathrm{dia})$, proteína bruta $(199,2 ; 181,5 ; 179,0 ; 175,2 \mathrm{~g} / \mathrm{dia})$ e o ganho de peso vivo $(298,275,280,255$ g/dia) diminuíram linearmente. Dessa forma, o autor concluiu que a inclusão do GS na ração dos cordeiros afetou negativamente o consumo de matéria seca e o ganho de peso vivo.

\subsection{DESEMPENHO E CARACTERÍSTICAS DE CARCAÇA DE BOVINOS DE CORTE}

O consumo é um dos principais fatores determinantes do desempenho animal, pois os ruminantes tendem a ajustá-lo às suas necessidades nutricionais, 
principalmente energéticas (FRASER, 1985). Uma alternativa para aumentar a fração energética da dieta é a suplementação com gorduras. Porém, as respostas à gordura na dieta são variáveis.

Brandt e Anderson (1995) verificaram que a suplementação de animais em fase de terminação com dietas contendo gordura aumentou o ganho diário e melhorou a eficiência alimentar, como resultado da maior energia metabolizável existente nos lipídeos em comparação aos carboidratos ou proteína. De acordo com Zinn (1992) e Brandt e Anderson (1995), a adição de gordura a dietas de terminação não afetou a digestibilidade total da matéria seca, matéria orgânica, mas aumentou o conteúdo energético da ração.

Entretanto, de acordo Clary et al. (1993) e Zinn e Shen (1996), a adição de gordura para animais em terminação reduziu a ingestão de matéria seca

Salla (2003) avaliou o fornecimento de diferentes fontes de lipídeos para vacas Jersey durante os primeiros 100 dias de lactação. As fontes testadas foram sebo, sais de cálcio de óleo de palma e grão de soja moído, representando respectivamente, gorduras predominantemente do tipo saturada, insaturada protegida e insaturada. $O$ autor não observou diferença entre os tratamentos para as características avaliadas e concluiu que as diferentes fontes de lipídeos não influenciaram as atividades do comportamento ingestivo, consumo de matéria seca e consumo de fibra em detergente neutro de vacas Jersey durante os primeiros 100 dias de lactação. Porém, fornecendo dietas contendo fontes de lipídeos (grão de soja moído e óleo de soja) em dois níveis (3 e 7\%) na dieta de vacas em lactação, Vargas (2002) observou redução de $20 \%$ do consumo de matéria seca.

Ainda em relação ao consumo de energia, pode haver modificação do uso da energia ingerida para a síntese de proteína ou lipídeos. Jones et al. (1985) observaram que animais alimentados com dietas à base de concentrado, apresentaram maiores teores de gordura na carcaça que aqueles cujas dietas eram à base de volumoso. Gesualdi Jr. et al. (2000) apontam para a falta de diferenças nas características relacionadas com a conformação da carcaça, quando os animais são alimentados com diferentes níveis de concentrado na dieta. No entanto, Brondani et al. (2006) verificaram melhora na conformação das carcaças, quando avaliada subjetivamente pela distribuição muscular, assim como pelo aumento no comprimento de perna e aumento da percentagem de músculo na carcaça para 
animais alimentados com alto teor de energia em comparação com animais alimentados com menor teor de energia na dieta.

Segundo Barber et al. (1981), a composição corporal afeta diretamente a eficiência de utilização de alimentos para ganho de peso vivo e para produção de carne comestível.

É de extrema importância a comparação das características das carcaças dos animais, pois desta maneira, torna-se possível detectar as diferenças existentes entre as mesmas, identificando àquelas que produzirão melhores rendimentos (CARVALHO, 1998) e consequentemente mais carne, já que o rendimento de carcaça é uma característica diretamente relacionada à produção de carne (URANO, 2005).

A informação acurada sobre as características de carcaça possibilita o direcionamento de práticas de manejo para aumentar a eficiência alimentar, viabilizando a produção de um animal com exigências específicas do mercado, especialmente quanto à espessura de gordura subcutânea ao abate, visto que sua ausência, além de influenciar negativamente os atributos de qualidade da carne, também causa perdas aos produtores, em razão dos descontos impostos pelos frigoríficos (LUZ; SILVA, 2006).

O peso de abate, o sexo, a nutrição e a raça afetam a composição da carcaça e são os principais fatores sobre os quais técnicos podem intervir, visando à alteração dessa composição (LUCHIARI FILHO, 2000). O peso de abate possui grande influência no desempenho, consumo e eficiência alimentar dos bovinos (ARBOITTE et al., 2004).

A área de olho lombo medida entre a $12^{a}$ e a $13^{a}$ costelas é amplamente aceita e utilizada como um indicador da composição de carcaça, e, apesar de apresentar pequena associação com a quantidade de carne magra (BERG; BUTTERFIELD, 1979), é internacionalmente aceita e amplamente utilizada (LUCHIARI FILHO, 2000).

A espessura de gordura subcutânea, também é avaliada na altura da $12^{a}$ costela, pode explicar de duas a três vezes mais a variação no rendimento de cortes comerciais do que a área de olho lombo e está altamente associada ao peso dos cortes (LUCHIARI FILHO, 2000).

Zinn et al. (2000), alimentaram novilhos holandeses com dietas contendo sais de cálcio de ácidos graxos e gordura animal, até o nível de $6 \%$ e concluíram que 
estas dietas não influenciaram a área de olho de lombo, ou a gordura subcutânea das carcaças avaliadas.

Aferri et al. (2005) estudaram novilhos mestiços 3/4 Europeu-Zebu tratados com dietas contendo $81 \%$ de concentrado e $21 \%$ de caroço de algodão na ração e verificaram que o uso de gordura protegida ou caroço de algodão não exerceu influência sobre o rendimento dos cortes cárneos, rendimento de carcaça e medidas de área de olho lombo e espessura de gordura subcutânea.

Huerta-Leidnenz et al. (1991) investigaram o impacto da adição de caroço de algodão em novilhos Hereford confinados e não observaram efeito deste sobre o peso de carcaça quente e espessura de gordura subcutânea. Entretanto, a área de olho de lombo foi maior para os animais alimentados com a dieta controle $(0 \%$ de caroço de algodão) em relação aos alimentados com 30\% de caroço de algodão.

Segundo Gibb et al. (2004), existe tendência ao aumento na eficiência, quando a concentração energética da ração é aumentada, pelo fato da gordura conter mais que o dobro do conteúdo de energia, quando comparada aos carboidratos, mas desde que o consumo de matéria seca não seja afetado.

A temperatura pode se tornar uma importante característica quando se avalia fatores que influenciam na maciez da carne, devido a sua influência no processo enzimático, pois, sem dúvida, existe uma aceleração da queda de $\mathrm{pH}$ em temperaturas próximas a $30^{\circ} \mathrm{C}$ (KOHAMARAIE et al., 2003).

A tendência dos consumidores, no momento da compra da carne, é avaliar a sua qualidade principalmente pela cor vermelha e, após consumi-la, também pela suculência, maciez e sabor (DRANSFIELD, 1994). Neste contexto, a habilidade para predizer acuradamente à palatabilidade (maciez, suculência e sabor) da carne é fundamental para proporcionar a satisfação do consumidor (MAY et al., 1992).

Segundo Yang et al. (1999), o grau de terminação também interfere na qualidade da carcaça de bovinos de corte. Quando os animais confinados são alimentados com dietas ricas em grãos, apresentam carne mais marmorizada, gordura com melhor coloração e produzem carcaças mais uniformes.

As gorduras contribuem para o sabor e aroma e determinam a natureza dos compostos produzidos pela oxidação durante o cozimento da carne. Os hidroperóxidos gerados nesta oxidação durante o cozimento produzem vários compostos voláteis como aldeídos, que indiretamente determinam o sabor e aroma 
por participarem da reação de Maillard (GEAY et al., 2001), que podem além do escurecimento produzir aromas indesejáveis,

Pesquisas realizadas por Ito (2005) constataram melhora na qualidade da carne, quando óleos vegetais (óleo de soja ou semente de linhaça) protegidos da degradação ruminal, foram fornecidos com dietas a base de silagem de milho, durante a terminação de bovinos.

Bartle et al. (1994) estudaram a inclusão de lipídeos na dieta de novilhos em confinamento, constatando que até $4,6 \%$ da matéria seca da dieta mantém os mesmos índices de desempenho animal e de características de carcaça.

Segundo May et al. (1992), o valor de força de cisalhamento está correlacionado com escore de marmorização, dias de confinamento, espessura de gordura e peso da carcaça.

Em experimento realizado por Shibuya (2004), 12 novilhos Nelore foram alimentados com quatro diferentes dietas, contendo na primeira milho seco; na segunda milho úmido; uma terceira dieta contendo milho seco + gordura protegida, e outra contendo milho úmido + gordura protegida, e outro bloco com 12 novilhos filhos de vacas cruzadas Simental x Nelore com touros Brangus foi alimentado com dietas contendo gordura protegida; caroço de algodão inteiro ou dieta controle. A autora concluiu que a inclusão de gordura protegida, milho úmido ou caroço de algodão na dieta dos animais, como fontes alternativas de energia alterou pouco, ou nada a percepção dos consumidores sobre os atributos sensoriais testados.

\subsection{SELÊNIO}

O selênio (Se), descoberto por Berzelius em 1817, foi primeiramente reconhecido como elemento tóxico para animais e humanos, sendo considerado, inicialmente, um agente carcinogênico. Somente em 1957 teve sua essencialidade comprovada para animais (SCHWARZ; FOLTZ, 1957) e em 1973 pesquisadores comprovaram seu papel biológico primariamente como componente da enzima glutationa peroxidase, participante do sistema antioxidante de defesa das células (FLOHÉ et al., 1973). 
Segundo McDowell (1992), o papel do selênio na nutrição animal foi descoberto quando se observou que a suplementação evitava necrose hepática em ratos. Após essa constatação, também foi relatada a prevenção de distrofia muscular quando bovinos e ovinos foram suplementados com selênio.

O requerimento de Se para bovinos de corte é de $0,1 \mathrm{mg} / \mathrm{kg}$ de $\mathrm{MS}$ e a concentração máxima estimada, para evitar problemas de toxidez é de $2 \mathrm{mg} / \mathrm{Kg}$ de MS (NRC, 2001), sendo que recentemente foi estabelecido o aumento deste nível para $5 \mathrm{mg} / \mathrm{kg}$ (NRC 2005).

O Se na forma de selenito ou selenato está naturalmente presente em grande concentração em algumas faixas de solo (LEHNINGER, 2000). Além das muitas interações entre elementos químicos, os fatores que agem sobre o equilíbrio físicoquímico do solo, tais como adubação e manejo das pastagens, podem afetar a disponibilidade de minerais para as plantas e consequentemente para os animais. $O$ impacto causado pela aplicação de grandes quantidades de fertilizantes químicos sobre o equilíbrio mineral do solo e, portanto, sobre o perfil mineral das plantas, irá refletir, por conseguinte, no status metabólico dos animais alimentados com estas forragens. Sendo assim, pastos ou volumosos oriundos de campos, que receberam adubação pesada com produtos à base de sulfato, têm baixo nível de captação de Se pelas plantas, uma vez que aumenta a competição pela absorção vegetal (BLOOD, 2002).

O Se é um mineral essencial na alimentação animal e exerce suas funções biológicas quando incorporado às proteínas, formando as selenoproteínas, das quais a glutationa peroxidase é uma das mais importantes. Esta enzima possui quatro átomos de selênio e é responsável pela redução de hidroperóxidos nas células, plasma e trato gastrintestinal, ocupando um papel central na proteção celular contra o ataque de radicais livres (HOLBEN, 1999), ou seja, como parte integrante da enzima glutationa peroxidase (GSH-Px), o Se previne danos por oxidação aos tecidos corporais. Além disso, antioxidantes podem ajudar na prevenção de doenças por reagirem com os radicais livres ou inibir os danos causados pelos mesmos (PAPAS, 1996).

Quando o fornecimento de Se na dieta é inadequado, as células animais apresentam diminuição na capacidade para inativar peróxidos. Não obstante, as concentrações plasmáticas de selênio e de glutationa peroxidase diminuem, fazendo com que os sinais da deficiência apareçam em evidência (NRC, 1983). 
O Se pode ser encontrado em duas formas químicas na natureza, na forma orgânica e na forma inorgânica. O selênio inorgânico pode ser encontrado na forma de Se elementar $\left(\mathrm{Se}_{0}\right)$, selênio reduzido $\mathrm{Se}_{-2}$ (seleneto) ou selênio oxidado $\mathrm{Se}_{+4}$ (selenito) e $\mathrm{Se}_{+6}$ (selenato).

O selênio orgânico presente nos alimentos encontra-se principalmente sob a forma de selenometionina (SURAI, 2006). As duas formas do mineral são metabolizadas de maneiras diferentes. As moléculas de selenometionina são inertes e absorvidas no jejuno, atravessam as células da mucosa intestinal e passam diretamente para o plasma. O mineral pode ser acumulado em tecidos como o fígado e o músculo. A separação do aminoácido quelante se dá no local onde o elemento é utilizado. O transporte para o interior das células se dá pela difusão passiva ou pelo transporte ativo (proteínas transportadoras). Nessas condições é que podem ocorrer perdas por reação com compostos, ou competição pelos sítios de absorção entre os elementos minerais com interações antagônicas que podem inibir a absorção. Grande parte do selênio inorgânico é excretado nas fezes e urina e muito pouco fica retido nos tecidos de reserva.

Um número grande de fatores pode influenciar na biodisponibilidade e distribuição do selênio no corpo como: forma química do mineral, outros compostos da dieta, status do selênio e espécie animal (SURAI, 2006).

O tecido muscular dos animais pode atuar como um potencial reservatório e fonte de selênio por sua capacidade de armazenar este nutriente.

Sabe-se que nos tecidos o selênio está presente em duas formas: como selenocisteína (SeCys) e selenometionina (SeM). A SeM não pode ser sintetizada no organismo e deve ser fornecida pela dieta. Esta espécie pode substituir a metionina em uma variedade de proteínas. A SeM é considerada como um forma de deposito de selênio. Quando o suporte de selênio da dieta é interrompido, este compartimento é movimentado e repõe o selênio no organismo (BURTIS et al., 2001).

A importância das selenoproteinas no metabolismo ajuda a explicar os efeitos adversos da deficiência de selênio na saúde humana e animal. Várias doenças crônicas tem sido relacionadas ao baixo status de Se. Baixas concentrações de Se no sangue tem sido associadas à incidência de infarto do miocárdio (HOLBEN et al., 1999). 
A ingestão de baixas quantidades de selênio também tem sido relacionada ao aumento do risco de câncer. Experimentos com modelos animais e estudos com humanos tem demonstrado efeito protetor de vários compostos de selênio, em níveis que excedem a nutrição, na inibição do crescimento de tumores (HOLBEN et al., 1999; RAYMAN, 2000).

Lawler et al. (2004), suplementando selênio em concentrações adequadas e acima das exigências para novilhos, não observaram alterações em diversas características de carcaça analisadas. Entretanto, foi observado aumento da concentração de Se no músculo Semitendinosus para o tratamento com grãos de trigo contendo altas concentrações de Se, quando comparados às outras fontes de selênio (feno, e selenito de sódio).

O Se orgânico, derivado de fontes como grãos e farelo de soja, tende a resultar em maiores concentrações no tecido muscular em não ruminantes, do que o Se inorgânico (ULLREY et al., 1977; MAHAN; MOXON, 1978; AMMERMAN et al., 1980; EKHOLM et al., 1991).

Paiva (2007) comparou dietas sem suplementação de selênio, dietas contendo 0,$2 ; 0,8$ e 1,4 mg/kg de Se na forma de selenito de sódio com dietas contendo as mesma quantidades de Se suplementar na forma de Se-metionina, fornecidas a 40 cordeiros da raça Suffolk, desmamados, castrados, com idade inicial de aproximadamente 90 dias e peso inicial de 19,8 $\pm 2,1 \mathrm{~kg}$. A autora concluiu que as fontes orgânicas de selênio, nos níveis utilizados no experimento, promoveram respostas semelhantes ao selenito de sódio, quando observados os resultados da concentração de selênio no soro, fígado e rim, da atividade da glutationa peroxidase no fígado e do balanço metabólico de selênio. Além disso, a inclusão de fontes orgânicas promoveu maiores concentrações de selênio no músculo dos animais, aumentando, a concentração de selênio na carne de cordeiros.

Pavlata et al. (2001) em estudo realizado com bezerros de um mês de idade recebendo 0,3 ppm de selênio orgânico, por um período de dois meses, observaram aumento das concentrações de selênio na musculatura estriada, de 0,092 g/g a $0,263 \mathrm{~g} / \mathrm{g}$.

Vinte e oito bovinos Brangus foram utilizados para determinação do efeito da suplementação de cobre e selênio no desempenho e características de carcaça. Foram utilizados quatro tratamentos, sendo um deles sem a suplementação de cobre e selênio, outro contendo $2 \mathrm{mg}$ de selênio por quilo de matéria seca na forma 
de selenito de sódio; um terceiro tratamento contendo $40 \mathrm{mg}$ de cobre por quilo de matéria seca na forma de sulfato de cobre; e outro contendo $2 \mathrm{mg}$ de selênio e 40 mg cobre por quilo de matéria seca nas mesmas apresentações dos tratamentos anteriores. O ganho de peso diário aumentou com a suplementação de selênio. A eficiência alimentar foi melhor nos tratamentos selênio, cobre e selênio/cobre, em relação ao controle. A ingestão de matéria seca não foi alterada pelos tratamentos, assim como a espessura de gordura no músculo LD (DEL CLARO, 2007).

A deficiência de selênio é reconhecida como um importante fator que afeta a saúde humana em todo mundo, dessa maneira, encontrar formas de disponibilidade deste mineral nos alimentos, torna-se um importante campo de pesquisa. 


\section{MATERIAL E MÉTODOS}

\subsection{Local de execução}

O experimento foi conduzido na Faculdade de Medicina Veterinária e Zootecnia (FMVZ) da USP, Campus de Pirassununga-SP, entre os meses de junho a outubro de 2007. O município de Pirassununga situa-se a $21^{\circ} 59^{\prime}$ de latitude Sul e $47^{\circ} 26^{\prime}$ de longitude Oeste e a uma altitude de 634 metros. O clima é tipo subtropical, com inverno seco e bem definido e verão quente e chuvoso.

Foram utilizados animais e instalações em uma área de confinamento experimental, com 18 baias parcialmente cobertas, piso cimentado, com bebedouros automáticos individuais. Cada grupo de três animais foi alojado em baias com dimensões de $26,7 \mathrm{~m}^{2}$.

\subsection{Animais}

Foram utilizados 54 machos, castrados, da raça Nelore (Bos taurus indicus), com idade média de 30 meses e com peso vivo médio de $458 \pm 39 \mathrm{~kg}$ no início do experimento.

\subsection{Alimentação}

Os animais foram distribuídos, de acordo com o peso inicial, em delineamento em blocos casualizados e arranjo fatorial de tratamentos do tipo $3 \times 2$, cujos fatores de variação foram três fontes de lipídeos (girassol, soja grão e caroço de algodão) e duas fontes de selênio (orgânico ou inorgânico). 
A dieta foi formulada com o auxílio do programa RLM 3.0 (LANNA et al., 2005), contendo $40 \%$ de volumoso a base de silagem de milho e $60 \%$ de concentrado, fornecidos em 18 baias, contendo 3 animais por baia, por um período de confinamento de aproximadamente 110 dias, precedido por um período de adaptação de 28 dias.O cálculo do consumo por animal foi feito a partir da média diária consumida pelos três animais de cada baia. Dessa maneira, considerou-se que para efeito de consumo que cada animal consumia a quantidade média dos três animais alojados em cada baia.

A alimentação foi fornecida uma vez ao dia, no período da manhã. Foram colhidas e pesadas as sobras da alimentação todos os dias e duas vezes por semana, determinada a matéria seca (MS) das sobras nos mesmo períodos. A quantidade de alimento foi ajustada em $5 \%$ duas vezes por semana com base no consumo anterior.

As dietas foram formuladas para que cada fonte de lipídeo fornecesse 3,5\% de óleo e as fontes de selênio orgânico (Selplex® 0,1\% Alltech - Lexington, Kentucky - EUA) e selênio inorgânico (Selenito de Sódio, 44,5\% - Nutron Alimentos Campinas, São Paulo - Brasil) 0,3 mg/kg de Se na MS, fornecidas nos seguintes concentrados:
A) GINITO - 10,38\% de semente de girassol + 0,3 mg de selênio inorgânico;
B) GIPLEX - 10,38\% de semente de girassol + 0,3 mg de selênio orgânico;
C) CANITO - 16,19\% de caroço de algodão + 0,3 mg de selênio inorgânico;
D) CAPLEX - 16,19\% de caroço de algodão + 0,3 mg de selênio orgânico;
E) SONITO - 13,71\% de soja grão + 0,3 mg de selênio inorgânico;
F) SOPLEX - 13,71\% de soja grão + 0,3 mg de selênio orgânico;

A formulação dos ingredientes do suplemento mineral, com adição de ambas as fontes de selênio, foi realizada na Unidade de Pesquisa da Nutron Alimentos, Unidade de Mogi Mirim-SP. Essa medida foi realizada para evitar qualquer tipo de contaminação ou mistura das fontes de selênio no sal mineral formulado.

A composição dos nutrientes e proporção de ingredientes distribuídos por fontes de lipídeos estão apresentadas na tabela 1. 
Tabela 1 - Proporção de ingredientes e composição bromatológica das dietas distribuídas por fontes de lipídeos em \% da matéria seca

\begin{tabular}{|c|c|c|c|}
\hline \multirow[b]{2}{*}{ Ingredientes (\%) } & \multicolumn{3}{|c|}{ Fontes de lipídeos } \\
\hline & $\begin{array}{c}\text { Semente de } \\
\text { girassol }\end{array}$ & $\begin{array}{c}\text { Caroço de } \\
\text { algodão }\end{array}$ & $\begin{array}{c}\text { Soja grão (in } \\
\text { natura) }\end{array}$ \\
\hline Silagem de Milho (35\% grão) & 40 & 40 & 40 \\
\hline Milho grão moído & 15,00 & 15,00 & 15,00 \\
\hline Semente de girassol & 13,00 & - & - \\
\hline Caroço de algodão & - & 16,70 & - \\
\hline Soja em grão (in natura) & - & - & 13,00 \\
\hline Casca de Soja & 30,25 & 26,80 & 25,25 \\
\hline Óleo de Soja & - & - & 1,10 \\
\hline Uréia & 0,58 & 0,20 & - \\
\hline Mistura mineral $^{1}$ & 0,60 & 0,60 & 0,60 \\
\hline Rumensin ${ }^{\circledR}$ & 0,027 & 0,027 & 0,027 \\
\hline Calcário & 0,70 & 0,70 & 0,70 \\
\hline \multicolumn{4}{|l|}{ Nutrientes } \\
\hline Proteína bruta, \% & 12,30 & 12,20 & 13,30 \\
\hline Proteína degradável rúmen, \% & 7,83 & 7,85 & 8,90 \\
\hline Nutrientes digestíveis totais \% & 71,59 & 73,70 & 71,59 \\
\hline Extrato etéreo, \% & 6,20 & 6,10 & 6,01 \\
\hline Se (mg) & 0,21 & 0,21 & 0,22 \\
\hline
\end{tabular}

\subsection{Pesagem dos animais}

As pesagens dos animais foram realizadas, em média, a cada 28 dias, após jejum completo de 18 horas, assim como a avaliação da espessura de gordura no músculo Longissimus dorsi, entre a $12^{a}$ e $13^{a}$ costelas, por meio de ultra-som. 


\subsection{Desempenho}

Os cálculos de desempenho foram realizados utilizando as medidas tomadas durante todo o período experimental. Foram calculados a ingestão de matéria seca (IMS), o ganho médio diário (GMD), a eficiência alimentar (EA) e a conversão alimentar (CA).

As análises laboratoriais foram realizadas no Laboratório de Análises de Alimentos de Origem Animal, do Departamento de Nutrição e Produção Animal da FMVZ-USP; no Laboratório de Tecnologia de Alimentos da FZEA-USP e no Laboratório de Análises de Alimentos do Departamento de Ciências dos Alimentos da UNICAMP - CAMPINAS - SP.

3.6 Abate dos animais e rendimento de carcaça

O abate foi realizado no abatedouro-escola da Prefeitura do Campus de Pirassununga da Universidade de São Paulo (PCAPS-USP), de acordo com os padrões determinados pelo RIISPOA (BRASIL, 1997), respeitando os requisitos de transporte, manejo, descanso, jejum e dieta hídrica.

Os abates dos bovinos foram realizados em três etapas, de acordo com o peso final dos animais, distribuído entre os tratamentos. Foram abatidos 12 animais em cada série, no Abatedouro Escola (PCAPS-USP) quando a espessura de gordura subcutânea atingiu, no mínimo $6 \mathrm{~mm}$ entre a $12^{\mathrm{a}}$ e $13^{\mathrm{a}}$ costelas.

Para o atordoamento dos animais, foi utilizada uma pistola pneumática, seguido pela sangria e evisceração, onde foram pesadas as gorduras perirenal e pélvica e o fígado dos animais. Ao final do abate, as carcaças foram divididas, utilizando-se serra elétrica, separando as meias-carcaças, que foram pesadas individualmente resultando no peso da carcaça quente (PCQ). Em seguida, foi realizada a limpeza e pesagem das meias carcaças quentes, e armazenadas em câmara frigorífica, com temperatura de 0 a $2^{\circ} \mathrm{C}$, por 24 horas. 
Após 24 horas, as carcaças foram novamente pesadas, obtendo-se o peso da carcaça fria (PCF), para cálculo do rendimento de carcaça (RC) e procedeu-se a desossa dos animais.

3.7 Características físico-químicas da carne fresca e maturada

\subsubsection{Temperatura e pH}

Uma hora após o abate foram determinados o $\mathrm{pH}(\mathrm{pH} 1 \mathrm{~h})$ e a temperatura (T1h) das carcaças, no músculo Longissimus dorsi (LD) de cada meia carcaça direita, usando-se um termômetro e peagâmetro digital com sondas de penetração (modelo HI8314 marca Hanna Instruments). Após 24 horas em câmara fria, foram reavaliados o $\mathrm{pH}$ e a temperatura das carcaças, no mesmo local.

\subsection{2 Área de olho de lombo, espessura de gordura subcutânea e índice de marmorização}

As avaliações da área de olho de lombo (AOL), da espessura de gordura subcutânea (EGS) e índice de marmorização (IM) foram realizadas utilizando o músculo Longissimus de cada meia carcaça esquerda. Foram medidas a AOL e EGS, entre a $12^{a}$ e $13^{a}$ costelas, utilizando-se uma grade reticulada, em centímetros quadrados $\left(\mathrm{cm}^{2}\right)$. Para avaliação da marmorização foi utilizado um padrão adaptado do Meat Evaluation Handbook (MEAT EVALUATION HANDBOOK, 1973), com sete níveis de marmorização, variando de 2 (Standard -) a 7,9 (Choice +). 


\subsubsection{Analise de maciez objetiva}

Para a análise de maciez objetiva, foi retirado um bife de $2,5 \mathrm{~cm}$ de espessura da meia carcaça esquerda do músculo Longissimus a partir da $13^{\text {a }}$ costelas, identificado e embalado a vácuo. As amostras foram maturadas por sete dias, em câmara frigorífica do Abatedouro-Escola entre 0 e $2^{\circ} \mathrm{C}$ e em seguida, foram congeladas $\mathrm{a}-20^{\circ} \mathrm{C}$ para posterior análise.

As análises de maciez foram realizadas no Laboratório de Carnes da FZEA/USP, conforme metodologia proposta por Wheeler, Koohmaraie e Shakelford (2004). Após serem descongeladas em refrigerador doméstico entre 5 e $7^{\circ} \mathrm{C}$, por 24 horas, as amostras foram assadas em temperatura de $170^{\circ} \mathrm{C}$ em forno elétrico até atingirem a temperatura interna no bife de $71^{\circ} \mathrm{C}$. As temperaturas foram medidas através de termômetros individuais (Good Cook Meat Thermometer) com um sensor metálico tipo agulha, inserido nos bifes até sua parte central. As amostras, acomodadas em bandejas de aço inox individuais, foram pesadas antes e logo após o cozimento para determinação da perda de água no cozimento.

As amostras foram levadas logo em seguida para um refrigerador doméstico, por um período de 24 horas. Foram retirados, em seguida, seis cilindros de $12 \mathrm{~mm}$ de diâmetro de cada bife, com auxílio de um vazador (WHEELER et al., 2001). A análise de maciez foi realizada com aparelho Warner-Bratzler Shear Force, para determinação da força de cisalhamento, considerando para cada bife o valor médio obtido nos seis cilindros.

\subsubsection{Análise de maciez subjetiva (Sensorial)}

Para os testes sensoriais, as amostras foram maturadas 7 dias após a desossa e depois congeladas segundo metodologia descrita por Wheeler et al. (2001), e na véspera da análise sensorial foram mantidas a $5^{\circ} \mathrm{C}$ por aproximadamente 24 horas. 
As amostras foram transportadas congeladas dentro de uma iogurteira (Marca Arno), até a UNICAMP-SP para a realização das análises por painel treinado na FEA/UNICAMP.

Após o descongelamento das mesmas, foram formadas seis amostras compostas pelas oito repetições de cada um dos seis tratamentos, totalizando 48 amostras. Foram realizadas quatro sessões para a avaliação, em quatro períodos diferentes (manhã e tarde) sendo que em cada período, os provadores tiveram à disposição para análise amostras de todos os tratamentos. Desta forma, foram realizadas oito repetições por tratamento, totalizando 48 amostras provadas em quatro sessões.

Os bifes foram assados em forno elétrico (IMEQUI, forno industrial tipo padaria) pré-aquecido a $170^{\circ} \mathrm{C}$, com quatro resistências, sendo duas superiores e duas inferiores. As amostras foram viradas quando a temperatura interna atingiu $40^{\circ} \mathrm{C}$ e foram assadas até atingirem a temperatura interna final de $71^{\circ} \mathrm{C}$, monitoradas por termômetro digital (SCS SOVEREIGN Modelo 692-8010). Após atingirem o ponto, elas foram cortadas em paralelepípedos de 1,0 x 1,0 x 2,5 cm, com auxílio de um molde formado por uma base e uma grade plástica $(14 \mathrm{~cm}$ comprimento $\times 10 \mathrm{~cm}$ de largura $\times 4 \mathrm{~cm}$ de profundidade), com fendas espaçadas $1,5 \mathrm{~cm}$ entre si, adaptado do método utilizado por Andrae et al. (2001). Posteriormente, as amostras foram acondicionadas em tubos de vidro e mantidos em temperatura aproximada de $65^{\circ} \mathrm{C}$, com auxílio de uma iogurteira. Os béqueres foram mantidos "tampados" a fim de evitar a evaporação e redução da temperatura das amostras, bem como para evitar a liberação de odor pelo ambiente de análise sensorial. As amostras foram entregues aos membros do painel em copos plásticos brancos descartáveis, uma de cada vez, a fim de se evitar comparação.

Foram avaliados atributos de suculência, maciez e sabor. Foi ainda questionado se o provador percebia alguma outra característica importante não avaliada segundo anexo $A$.

As análises foram realizadas em cabines individuais, para avaliação do aroma, textura, suculência e sabor, de acordo com a metodologia da AMSA (1995). A avaliação foi realizada utilizando-se escala hedônica estruturada de oito pontos, variando de "ausente" (nota 1) a "extremamente forte" (nota 8) para os itens: aroma característico, aroma estranho, sabor característico e sabor estranho. Para os itens textura e suculência, a classificação variou de, respectivamente, "extremamente 
dura" (nota 1) a "extremamente macia" (nota 8), e de "extremamente seca" (nota 1) a "extremamente suculenta" (nota 8).

\subsubsection{Análises de Colesterol}

As análises de colesterol foram realizadas no Laboratório de Química Biológica da FZEA-USP, no departamento de Engenharia de Alimentos. As amostras do músculo Longissimus permaneceram congeladas a $-25^{\circ} \mathrm{C}$ até o momento das análises.

A análise de colesterol no músculo foi realizada de acordo com o método Saldanha et al. (2004), adaptado, por meio de método enzimático, utilizando-se $2 \mathrm{~g}$ do músculo Longissimus, referente ao dia zero de maturação. A leitura da absorbância foi realizada após 10 minutos.

\subsection{Análise estatística}

O delineamento experimental utilizado foi o de blocos casualizados, sendo o peso o critério de bloco, em arranjo fatorial 3x2 (3 fontes de lipídeos $\times 2$ fontes de selênio). Os efeitos das fontes de lipídeos, de selênio e das interações foram verificados por análise de variância, por meio do procedimento MIXED do software SAS $^{\circledR}$ (SAS Institute INC., Cary, NC) ao nível de 5\% de significância. Quando foi verificado efeito significativo das fontes de lipídeos, as médias foram comparadas pelo teste $\mathrm{T}$. 


\section{RESULTADOS E DISCUSSÃO}

\subsection{Desempenho}

Os resultados médios de peso vivo, ganho diário, matéria seca ingerida e conversão alimentar, em função das fontes de lipídeos fornecidas, estão apresentados na tabela 2 .

Tabela 2 - Peso vivo final (PVF), ganho médio diário (GMD), matéria seca ingerida (MSI), e conversão alimentar (CA) em função das fontes de lipídeos fornecidas na dieta

\begin{tabular}{|c|c|c|c|c|c|}
\hline & \multicolumn{3}{|c|}{ Fontes de lipídeos } & \multirow[b]{2}{*}{$\begin{array}{c}\text { Erro } \\
\text { Padrão }\end{array}$} & \multirow[b]{2}{*}{$\mathrm{P}$} \\
\hline & $\begin{array}{l}\text { Caroço de } \\
\text { algodão }\end{array}$ & $\begin{array}{c}\text { Semente de } \\
\text { girassol }\end{array}$ & $\begin{array}{l}\text { Soja "in } \\
\text { natura" }\end{array}$ & & \\
\hline $\mathrm{PVF}(\mathrm{Kg})^{1}$ & $593,25^{a}$ & $562,25^{b}$ & $575,27^{a b}$ & 7,85 & 0,02 \\
\hline $\operatorname{GMD}(\mathrm{Kg})^{2}$ & 1,13 & 1,07 & 1,09 & 0,03 & 0,67 \\
\hline $\mathrm{MSI}(\% / \mathrm{PV})^{3}$ & 1,98 & 1,90 & 1,94 & 0,04 & 0,15 \\
\hline $\mathrm{CA}(\mathrm{Kg})^{4}$ & 9,3 & 8,8 & 9,21 & 0,39 & 0,60 \\
\hline
\end{tabular}

Foi observado efeito das fontes de lipídeos sobre o peso vivo final $(P=0,02)$, sendo que os animais que receberam caroço de algodão apresentaram maior peso médio com 593,25 kg, do que aqueles que receberam semente de girassol, com média de $562,25 \mathrm{~kg}$. Os animais que receberam soja não apresentaram diferença com os outros tratamentos, com média de $575,27 \mathrm{~kg}$. O peso vivo é o critério mais comum utilizado na avaliação do desempenho animal e de carcaça e apesar de fornecer apenas indicação do estádio de desenvolvimento do animal (LUCHIARI FILHO, 2000), tem grande influência no desempenho, consumo, eficiência alimentar e composição da carcaça (TAUBES, 2001; ARBOITTE et al., 2004). Porém, este por si só não pode dar uma idéia da composição e do grau de rendimento de uma carcaça (LUCHIARI FILHO, 2000).

Em avaliação do desempenho de novilhos Nelore confinados com dois níveis de caroço de algodão (15 ou $30 \%$ da MS), associados à cana-de-açúcar ou capim 
elefante, Prado et al. (1995) não constataram diferença entre os tratamentos, tanto para ganho de peso diário, como para ingestão diária de matéria seca. De forma similar, Aferri et al. (2005) observaram que o uso de caroço de algodão não resultou em ganho de peso diário e ingestão de matéria seca diferentes do tratamento controle que não continha caroço de algodão.

Paulínio et al. (2002) encontraram resultados semelhantes ao presente estudo. Os autores forneceram dietas com caroço de algodão inteiro, soja grão e farelo de soja para novilhos e não verificaram diferenças no ganho de peso dos animais, cuja a média do GMD de $1,070 \mathrm{~kg}$.

O ganho médio diário $(P=0,88)$, a matéria seca ingerida $(P=0,35)$ e a conversão alimentar $(P=0,66)$, não foram influenciados pelas fontes de lipídeos. Existe a tendência ao aumento na eficiência quando a concentração energética da ração é aumentada, mas desde que o consumo de matéria seca (CMS) não seja afetado. No presente estudo não foi verificada diferença na eficiência entre as dietas contendo diferentes fontes de energia.

Melo et al. (2006), contrariamente aos resultados deste estudo, observaram aumento linear no CMS em vacas holandesas em lactação recebendo dieta controle, com adição de zero, $6,25 \%, 12,5 \%, 18,75 \%$ e $25 \%$ de caroço de algodão em substituição à silagem de sorgo e ao farelo de soja, em dieta à base de palma forrageira, sendo o consumo de MS (Kg/dia) de 21,43; 21,38; 22,03; 24,27 e 23,50 respectivamente por animal. Estes resultados demonstram melhor eficiência da dieta contendo caroço de algodão, quando comparada ao grupo controle, o que segundo o autor, está associado à diferença do tamanho de partícula e à gravidade específica da silagem de sorgo e do caroço de algodão, que interferem na taxa de passagem das dietas experimentais.

Resultados encontrados por Brosh et al. (1989), utilizando caroço de algodão da dieta de bovinos em confinamento, diferiram dos resultados deste estudo. Os autores concluíram que este alimento fornecido acima de $12 \%$ na ração acarreta diminuição no ganho de peso sem alterar o consumo de MS. Da mesma maneira, Coppock, Lanham e Horner (1987) mostraram não haver diferença no consumo de MS por bovinos, quando a semente de algodão integral foi incluída na proporção de até $25 \%$ da dieta, o que vai de encontro aos resultados obtidos com o presente estudo. 
Rogério et al. (2004) estudando a inclusão de caroço de algodão na dieta de ovinos ( 0 a $45 \%$ do total fornecido) observaram que a inclusão do caroço de algodão em $24 \%$ do total das dietas, apresentou aumento no CMS, em relação aos outros tratamentos. Alguns estudos demonstraram que dietas contendo fontes de lipídeos promoveram melhor eficiência e conversão alimentar (PAULINO et al., 2002), diferentemente dos resultados observados no presente estudo.

Segundo Huerta-leidenz et al. (1991) a inclusão de 15 ou 30\% de caroço de algodão na ração de bovinos cruzados Hereford $X$ Angus terminados por um período de 56 dias em confinamento não resultou em ganho médio diário e conversão alimentar diferentes.

Paulino et al. (2002) concluíram que o emprego de grão de soja ou caroço de algodão em suplementos para terminação de bovinos em pastejo durante a época seca, propiciou ganhos de peso animal semelhante ao obtido com a fonte protéica padrão de farelo de soja em um período de confinamento de três meses sendo peso inicial dos animais. Da mesma maneira, Garcia (2005) não verificou diferença do consumo de matéria seca, em dietas contendo duas fontes de lipídeos (soja grão tostada e caroço de algodão), fornecidas a vacas holandesas.

Os resultados encontrados por Duarte et al. (2005) foram similares aos do presente estudo, uma vez que não foi verificado efeito de fontes de lipídeos (sebo bovino; gordura protegida comercial e concentrado com grão de soja) na dieta de vacas Jersey, no consumo de matéria seca. Porém, o autor também não observou efeito sobre o peso vivo médio dos animais, divergindo dos resultados encontrados neste estudo.

Segundo Owens et al. (1993), bovinos jovens apresentam melhor conversão alimentar ( $\mathrm{kg}$ de $\mathrm{MS} / \mathrm{kg}$ de ganho). À medida que o animal se aproxima da maturidade, ponto no qual cessa a deposição de tecido muscular, inicia-se maior deposição de gordura (tecido adiposo) no corpo do animal, refletindo em pior conversão alimentar e maiores custos para ganho de peso. Desta maneira, sugerese que a idade inicial e peso avançado dos animais utilizados neste estudo, poderiam explicar a ausência de diferença entre os tratamentos quando avaliada a conversão alimentar dos animais.

Urano (2005) alimentou cordeiros com teores crescentes de grão de soja (GS) e concluiu que a inclusão do GS na ração dos cordeiros afetou negativamente o 
consumo de matéria seca e o ganho de peso vivo, diminuindo linearmente os dois parâmetros estudados, o que difere dos resultados encontrados neste estudo.

\subsection{Efeitos da fonte de Selênio}

As médias de peso vivo, ganho médio diário, matéria seca ingerida e conversão alimentar, em função da fonte de selênio fornecida, constam na tabela 3.

Tabela 3 - Peso vivo final (PVF), ganho médio diário (GMD), matéria seca ingerida (MSI), e conversão alimentar (CA) em função das fontes de selênio fornecida na dieta

\begin{tabular}{|c|c|c|c|c|}
\hline & \multicolumn{2}{|c|}{ Fontes de Selênio } & \multirow[b]{2}{*}{ Erro Padrão } & \multirow[b]{2}{*}{$\mathrm{P}$} \\
\hline & Orgânico & Inorgânico & & \\
\hline PVF $(\mathrm{Kg})^{1}$ & 567,42 & 586,72 & 6,41 & 0,03 \\
\hline GMD $(\mathrm{Kg})^{2}$ & 1,08 & 1,13 & 0,03 & 0,29 \\
\hline $\mathrm{MSI}(\% / \mathrm{PV})^{3}$ & 1,9 & 1,98 & 0,03 & 0,08 \\
\hline $\mathrm{CA}(\mathrm{Kg})^{4}$ & 9,00 & 9,16 & 0,32 & 0,72 \\
\hline
\end{tabular}

Foi observada diferença em relação ao peso vivo final $(P=0,03)$, entre os animais consumindo as fontes de selênio orgânica e inorgânica (Tabela 3). Resultados diferentes foram encontrados por Paiva (2007) avaliando a utilização de fontes orgânicas de selênio (Se) com o selenito de sódio na dieta de cordeiros. A autora não observou diferença entre os tratamentos no peso vivo (PV), com média de $38,63 \mathrm{~kg}$ e da ingestão de matéria seca média (IMS), com média de 1,33 kg nos animais ao final dos 84 dias de experimento. Da mesma forma, Lawler et al. (2004), trabalhando com novilhos, realizaram suplementação de selênio provindo de diferentes fontes com doses acima daquelas preconizadas pelo NRC, e também não encontraram alteração no ganho médio diário, matéria seca ingerida e conversão alimentar.

Não foi observada diferença entre as fontes de selênio para as características de ganho médio diário $(P=0,54)$, matéria seca ingerida $(P=0,13)$ e conversão alimentar $(P=0,75)$. 
Paschoal (2007), não encontrou efeito das dietas experimentais (dieta controle, $21 \%$ de soja extrusada e $21 \%$ de soja extrusada $+5 \mathrm{mg}$ de selênio orgânico) sobre a ingestão de matéria seca e peso vivo de vacas leiteiras. Da mesma maneira, Gunter et al. (2003) observaram que o peso corporal não diferiu entre vacas (cruzamento de Angus x Hereford e Simental) suplementadas com Se e vacas que não receberam nenhuma fonte de Se, assim como entre vacas suplementadas com selenito de sódio e selênio-levedura, demonstrando ausência de relação entre fornecimento de selênio e alteração no ganho de peso.

\subsection{Características de carcaça e da carne}

\subsubsection{Fontes de lipídeos}

As médias das características de carcaça dos animais utilizados neste estudo, em função das fontes de lipídeos (caroço de algodão, semente de girassol e soja "in natura"), estão apresentadas na tabela 4.

Tabela 4 - Características de carcaça, em função das fontes de lipídeos fornecidas na dieta

\begin{tabular}{|c|c|c|c|c|c|}
\hline & \multicolumn{3}{|c|}{ Fontes de lipídeos } & \multirow[b]{2}{*}{$\begin{array}{l}\text { Erro } \\
\text { Padrão }\end{array}$} & \multirow[b]{2}{*}{$P$} \\
\hline & $\begin{array}{l}\text { Caroço de } \\
\text { algodão }\end{array}$ & $\begin{array}{l}\text { Semente de } \\
\text { girassol }\end{array}$ & $\begin{array}{l}\text { Soja "in } \\
\text { natura" }\end{array}$ & & \\
\hline $\mathrm{PCQ}, \mathrm{Kg}^{1}$ & $361,13^{a}$ & $342,72^{b}$ & $350,87^{\mathrm{ab}}$ & 4,70 & 0,02 \\
\hline $\mathrm{RC}, \%^{2}$ & 60,94 & 60,95 & 61,05 & 0,37 & 0,97 \\
\hline$P G, \mathrm{~kg}^{3}$ & 19,08 & 18,33 & 19,37 & 0,73 & 0,58 \\
\hline $\mathrm{PF}, \mathrm{kg}^{4}$ & 5,92 & 5,84 & 5,80 & 0,14 & 0,81 \\
\hline $\mathrm{pH}$, zero hora ${ }^{5}$ & 6,56 & 6,61 & 6,62 & 0,08 & 0,87 \\
\hline $\mathrm{pH}, 24$ horas $^{6}$ & 5,74 & 5,72 & 5,73 & 0,04 & 0,97 \\
\hline Temp. zero hora $\left(\mathrm{C}^{0}\right)^{7}$ & 35,43 & 35,96 & 35,82 & 0,34 & 0,54 \\
\hline $\mathrm{AOL}\left(\mathrm{cm}^{2}\right)^{8}$ & 78,83 & 78,94 & 78,16 & 1,92 & 0,96 \\
\hline $\operatorname{EGS}(\mathrm{mm})^{9}$ & 8,30 & 8,44 & 9,33 & 0,71 & 0,55 \\
\hline $\mathrm{IM}^{10}$ & 6,42 & 6,33 & 6,44 & 0,25 & 0,94 \\
\hline $\mathrm{FC}(\mathrm{Kg})^{11}$ & 3,99 & 3,99 & 3,85 & 0,19 & 0,84 \\
\hline Colesterol $(\mathrm{mg} / 100 \mathrm{~g})^{12}$ & 106,82 & 103,25 & 102,80 & 3,33 & 0,64 \\
\hline Selênio $(\mathrm{mg} / \mathrm{kg})^{13}$ & 0,137 & 0,135 & 0,133 & 0,01 & 0,93 \\
\hline
\end{tabular}


Foi observado efeito das fontes de lipídeos sobre $P C Q(P=0,02)$. Porém não foi encontrada diferença para as características de $R C(P=0,97)$, peso da gordura $(P=0,58)$ e peso do fígado e $(P=0,81)$, $\mathrm{PH}$ zero hora e 24 horas $(P=0,87$ e $P=0,97)$, respectivamente, assim como para temperatura das carcaças avaliadas no tempo zero hora $(P=0,73)$, independente das fontes de lipídeos utilizada na dieta.

Avaliando a influência de teores crescentes de grão de soja em rações com alta proporção de concentrado para cordeiros Santa Inês, Urano (2005) não observou diferença entre os tratamentos para o $P C Q$ e o RC, o que difere dos resultados encontrados no presente estudo para $\mathrm{PCQ}$.

Paulino et al. (2002) avaliaram suplementos múltiplos contendo soja grão e caroço de algodão inteiros, em relação ao suplemento padrão de milho mais farelo de soja, em bovinos mestiços terminados a pasto. Os autores não observaram diferença entre os suplementos para o RC.

Quando avaliada a temperatura 24 horas pós-abate, foi verificada interação entre fontes de lipídeos e fontes de selênio $(P=0,04)$.

Os animais tratados com semente de girassol e selênio inorgânico (Ginito) apresentaram maiores temperaturas na carcaça, quando comparados aqueles que consumiram caroço de algodão e selênio inorgânico (Canito) $(P=0,02)$. $O$ tratamento Canito também foi diferente do tratamento contendo soja "in natura" e selênio inorgânico (Sonito), $(P<0,01)$. A temperatura da carcaça dos animais consumindo Ginito foi maior $\left(6,30^{\circ} \mathrm{C}\right)$, quando comparados àqueles tratados com Canito $\left(5,16^{\circ} \mathrm{C}\right)$ $(P=0,02)$.

Não foi observada diferença para AOL em função dos tratamentos estudados $(P=0,96)$ com média $78,64 \mathrm{~cm}^{2}$, corroborando com resultados encontrados por Muller et al. (2005) utilizando como fonte gordura a semente de linho e gordura protegida (GOP - Lac100®) obtendo média de 62,36 $\mathrm{cm}^{2}$. Zinn et al. (2000), fornecendo dietas de sais de cálcio de ácidos graxos e gordura animal, também não encontraram diferença na área de olho de lombo dos animais alimentados com diferentes fontes de lipídeos com média de $91,35 \mathrm{~cm}^{2}$.

Não foi observada diferença entre as fontes de lipídeos para a EGS $(P=0,55)$. A avaliação das características de AOL e EGS tem grande importância, já que são indicadores da carcaça mais comumente utilizados, assim como o peso da carcaça (quente ou resfriada), além da porcentagem da gordura renal e pélvica (LUCHIARI, 2000). 
Aferri et al. (2005) estudando o fornecimento de dietas contendo $81 \%$ de concentrado e $21 \%$ de caroço de algodão na ração a novilhos mestiços verificaram que o uso de gordura protegida ou caroço de algodão não influenciou o rendimento de carcaça, a de área de olho lombo e espessura de gordura subcutânea das carcaças avaliadas.

Resultados diferentes ao presente estudo foram encontrados por Moletta (1999), que confinou novilhos com idade inicial de 12 meses por sete meses e fez a inclusão de grão de soja ou caroço de algodão nas dietas fornecidas aos animais. $O$ autor encontrou como resultado valores de espessura de gordura de 3,08 $\mathrm{mm}$ para as carcaças dos animais que se alimentaram com grão de soja e 3,42 mm para os animais que se alimentaram com caroço de algodão. Os resultados encontrados demonstram que existe tendência dos animais alimentados com caroço de algodão, apresentarem maior rendimento e deposição de gordura nas carcaças quando comparados aos animais recebendo a outra dieta.

O presente estudo apresentou um longo período de confinamento, sendo este de aproximadamente 120 dias, precedido por um período de adaptação de 28 dias, podendo assim explicar a ausência de diferenças para a EGS e AOL entre os animais recebendo as diferentes dietas experimentais. Da mesma forma, pode não ter ocorrido influência dos tratamentos nesta característica pelo fato dos animais utilizados neste estudo serem avaliados em uma fase específica de deposição de gordura e já terem alcançado o máximo potencial de desenvolvimento do tecido muscular. De acordo com Menezes et al. (2005), a espessura de gordura subcutânea, atributo importante da carcaça, deve se situar entre 3 e $6 \mathrm{~mm}$, faixa que os frigoríficos consideram adequada, inclusive com possibilidades bonificação aos produtores rurais. Verificou-se neste estudo, que a EGS presente nas carcaças foi significativamente maior, valores explicados pela idade um pouco mais avançada dos animais.

Por outro lado, Bartle et al. (1994), verificaram valores de EGS maiores, com média de 11,3 mm, em novilhos em fase de terminação, quando estes consumiram quantidades maiores de gordura animal na dieta.

No presente estudo, os índices de marmorização não diferiram entre os animais tratados com as diferentes fontes de lipídeos na dieta $(P=0,94)$. De qualquer forma, é válido observar que o $\mathrm{m}$. Longissimus teve médias elevadas de marmorização $(6,40)$, especialmente por se tratar de animais zebuínos, que tendem 
a apresentar ausência ou ainda quantidades mínimas de marmorização nos cortes cárneos (BIANCHINI, 2005).

Segundo Yang et al. (1999), os animais confinados que são alimentados com dietas ricas em grãos, apresentaram carne mais marmorizada. Porém, não foi observada diferença entre as três fontes de lipídeoss testadas no presente estudo quando estudada a característica de marmorização das carnes.

Não foram observados efeitos das fontes de lipídeos na dieta dos bovinos, sobre a força de cisalhamento $(P=0,84)$, concentração de colesterol na carne $(P=0,64)$ e os níveis de selênio no $m$. Longissimus $(P=0,93)$.

A medida da força de cisalhamento (FC), através do método de WarnerBratzler, é uma das formas mais difundidas para se avaliar a maciez de um corte cárneo, pela sua alta correlação com os painéis sensoriais (SHACKELFORD et al., 1997). Fornecendo caroço de algodão para bovinos, Pesce (2008) também não encontrou diferença para a característica de força de cisalhamento entre os cortes oriundos dos animais recebendo os tratamentos contendo entre zero e $20 \%$ da semente oleaginosa. Aferri et al. (2005) também não encontraram diferença entre os tratamentos para FC aos 7 e 14 dias de maturação, avaliada no m. Longissimus de novilhos mestiços alimentados com dietas de alto concentrado, contendo caroço de algodão ou sais de cálcio de ácidos graxos.

Metade do colesterol do organismo origina-se da produção endógena e o restante, nos alimentos ingeridos (LEHNINGER, 2000). Por conseguinte, o conhecimento do teor de colesterol da dieta torna-se importante, pois altos níveis de colesterol estão associados com a incidência de doenças cardíacas e a ingestão de ácidos graxos saturados aumenta o colesterol do sangue (BENDER, 1992).

Não foram observados efeitos das fontes de lipídeos na dieta dos bovinos, sobre Extrato Etéreo $(P=0,79)$ (Tabela 5$)$.

Tabela 5 - Extrato Etéreo na carcaça, em função das fontes de lipídeos fornecidas na dieta

Fontes de lipídeos

Caroço de algodão Semente de girassol Soja "in natura" P

\begin{tabular}{lllll}
\hline EE, $\%^{1}$ & 3,78 & 3,49 & 3,75 & 0,79 \\
\hline${ }^{1}$ EE: extrato etéreo na matéria original & & &
\end{tabular}




\subsubsection{Fontes de Selênio}

As médias das características de carcaça dos animais utilizados neste estudo, em função da fonte de selênio fornecida, constam na tabela 6.

Tabela 6 - Características de carcaça em função das fontes de Se fornecidas na dieta

\begin{tabular}{|c|c|c|c|c|}
\hline & Fon & Selênio & & \\
\hline & Orgânico & Inorgânico & Erro Padrão & $\mathrm{P}$ \\
\hline $\mathrm{PCQ}, \mathrm{Kg}^{1}$ & 356,08 & 347,07 & 3,84 & 0,10 \\
\hline $\mathrm{RC}, \%^{2}$ & 61,22 & 60,74 & 0,30 & 0,27 \\
\hline$P G, \mathrm{~kg}^{3}$ & 17,68 & 20,17 & 0,60 & 0,01 \\
\hline $\mathrm{PF}, \mathrm{kg}^{4}$ & 5,69 & 6,02 & 0,11 & 0,04 \\
\hline $\mathrm{pH}$, zero hora $^{5}$ & 6,50 & 6,69 & 0,07 & 0,07 \\
\hline $\mathrm{pH}, 24$ horas $^{6}$ & 5,73 & 5,74 & 0,03 & 0,92 \\
\hline Temp. zero hora $\left(\mathrm{C}^{\circ}\right)^{7}$ & 35,91 & 35,57 & 0,28 & 0,40 \\
\hline $\mathrm{AOL}\left(\mathrm{cm}^{2}\right)^{8}$ & 79,25 & 78,03 & 1,57 & 0,58 \\
\hline $\mathrm{EGS}(\mathrm{mm})^{9}$ & 8,74 & 8,64 & 0,58 & 0,91 \\
\hline $\mathrm{IM}^{10}$ & 6,36 & 6,43 & 0,21 & 0,81 \\
\hline $\mathrm{FC}(\mathrm{Kg})^{11}$ & 3,84 & 4,05 & 0,15 & 0,34 \\
\hline Colesterol $(\mathrm{mg} / 100 \mathrm{~g})^{12}$ & 104,30 & 104,28 & 2,71 & 0,99 \\
\hline Selênio $(\mathrm{mg} / \mathrm{kg})^{13}$ & 0,148 & 0,122 & 0,01 & 0,01 \\
\hline
\end{tabular}

O PCQ, e o RC não foram influenciados pelas fontes de selênio $(P=0,10)$ e $(P=0,27)$, respectivamente. Entretanto o peso da gordura e do fígado foram influenciados pelas fontes de selênio $(P<0,05)$. O peso da gordura dos animais tratados com selênio inorgânico foi maior, com média de $20,17 \mathrm{~kg}$, quando comparado ao peso dos animais recebendo selênio orgânico na dieta, apresentando com médias de 17,68 kg.

$\mathrm{O} \mathrm{pH}$ zero hora $(\mathrm{P}=0,07), \mathrm{pH} 24$ horas $(\mathrm{P}=0,92)$ das carcaças não foram influenciados pelas fontes de selênio da dieta, assim como a temperatura das carcaças (temp. zero hora) $(P=0,40)$, área de olho de lombo $(P=0,58)$, espessura de gordura subcutânea $(P=0,91)$ e índice de marmorização $(P=0,81)$. 
Corroborando com os resultados do presente estudo, Del Claro (2007) não observou efeito da suplementação de cobre ou selênio em diferentes dietas ou selênio e cobre na mesma dieta, sobre a espessura de gordura e área de olho de lombo, tanto na altura da $5^{\mathrm{a}}$ quanto na da $12^{\mathrm{a}}$ costelas. Resultados similares também foram encontrados por Lawler et al. (2004). Estes autores forneceram selênio orgânico para novilhos e não constataram alterações na espessura de gordura subcutânea, ou área de olho de lombo, avaliadas na carcaça.

Em estudo realizado por Lawler et al. (2004), com suplementação de selênio na forma de selenito de sódio na concentração de 0,3 a 2,8 ppm para novilhos, não se observou alteração na espessura de gordura e marmorização da carne, assim como no presente experimento.

Não houve efeito das fontes de selênio sobre a força de cisalhamento (FC) $(P=0,34)$ e concentrações de colesterol no m. Longissimus $(P=0,99)$.

Em estudo com bovinos, Del Claro (2007) verificou efeito da fonte de selênio sobre as concentrações de colesterol no m. Longissimus. O colesterol muscular, no tratamento com $2 \mathrm{mg} / \mathrm{kg}$ de selênio suplementados, apresentou menor concentração que o tratamento controle com 0,06 mg/kg. Alguns autores, como, Kang et al. (1998); Cases et al. (1999); Kang et al. (2000a) e Kang et al. (2000b) relataram diminuição de LDL ou colesterol total com a suplementação de selênio.

Não foi observada diferença entre fontes de selênio $(P=0,79)$ para o $E E$ (Tabela 7). De maneira geral, os animais que consumiram as três dietas, independente do tratamento, obtiveram valores elevados de EE na carne. Esses resultados acompanharam àqueles de marmorização, visto que essa característica também não apresentou diferença entre os tratamentos.

A carne dos animais alimentados com selênio inorgânico apresentou médias de $E E$ de $3,73 \%$, enquanto àquelas de animais alimentados com fonte orgânica tiveram médias de 3,62\%. Esses resultados seguiram a característica do IM, que não diferiu entre os animais tratados com as diferentes fontes de selênio na dieta, cujos resultados são similares aos descritos por Lawler et al. (2004). 
Tabela 7 - Extrato Estéreo da carcaça em função das fontes de Se fornecidas na dieta

\begin{tabular}{lccc}
\hline & \multicolumn{2}{c}{ Fontes de Selênio } & \\
\cline { 2 - 3 } & Orgânico & Inorgânico & $\mathrm{P}$ \\
\hline $\mathrm{EE}, \%{ }^{1}$ & 3,62 & 3,73 & 0,79 \\
\hline 'EE: extrato etéreo na matéria original & &
\end{tabular}

Houve efeito da fonte de selênio ( $P=0,01)$ quando avaliada a concentração de selênio no $\mathrm{m}$. Longissimus dos bovinos, sendo que os maiores valores foram encontrados para a fonte de Se orgânica com médias de $0,148 \mathrm{mg} / \mathrm{kg}$, quando comparada à forma de suplementação inorgânica, com médias de 0,122 mg/kg. Este resultado vai de encontro com o observado por Ullrey et al. (1977), em ovinos e bovinos, Ammerman et al. (1980), em estudo com bovinos e Ekholm et al. (1991), trabalhando com touros.

Lawler et al. (2004), encontrou valores de 1,33; 1,55; 3,32; 4,41 ppm de Se no m. Longissimus de novilhos com suplementação de selênio na forma de selenito de sódio nas concentrações de 0,38;2,84; 2,80 e 2,86 ppm respectivamente, apontando valores diferentes, porém próximos dos encontrados neste experimento.

Similar ao observado neste experimento, Paiva (2007) relatou que o uso de fonte orgânica de selênio nestes níveis, resultou em maiores concentrações de selênio no músculo de cordeiros, com aumento, conseqüente, da concentração de selênio no músculo dos animais. Semelhantemente ao presente estudo, Lawler et al. (2004) observaram aumento substancial da concentração de Se no músculo Semitendinosus de novilhos alimentados com alimentos de elevado teor em Se, especialmente grãos de trigo.

O'Grady et al. (2001) adicionaram Se orgânico e vitamina E ao concentrado para 28 bovinos cruzados com pesos médios de $390 \mathrm{Kg}$. Os pesquisadores não verificaram diferença na concentração de selênio no músculo entre os tratamentos. Os resultados devem-se, provavelmente, pelo fato da quantidade de Se fornecida aos animais em experimentação não ter sido limitante para a demanda de Se dos tecidos independentemente da fonte. 
A maior concentração de selênio no músculo dos animais que receberam a fonte de selênio orgânica pode ser explicada porque a selênio-metionina pode ser incorporada diretamente ao tecido muscular (LEVANDER, 1986), pois uma parte significativa deste complexo escapa da hidrólise no rúmen, é absorvida no intestino (KOENIG et al., 1997), e incorporada a proteínas do músculo e de outros órgãos (PAVLAT et al., 2001). Já o selênio proveniente do selenito de sódio não pode ser incorporado diretamente à proteína muscular (HILDEBRAND, 1992) e o excesso de selênio inorgânico absorvido e não utilizado na síntese de selenoproteínas é excretado (ITOH; SUZUKI, 1997).

\subsubsection{Análise Sensorial}

Para todos os atributos sensoriais avaliados foram observadas diferenças significativas entre os provadores $(P<0,01)$. Este comportamento também foi observado por Shibuya (2004) e por Wheeler et al. (2004), em experimentos similares, realizando analise sensorial com provadores treinados.

Os provadores são solicitados para avaliar produtos com base em reações subjetivas e pessoais (MILLER, 2003). O ponto final do treinamento é indicado pela homogeneidade da equipe e repetibilidade dos resultados. Diferenças entre 0 provador podem indicar que, apesar do treinamento, os provadores usaram diferentes porções da escala para expressar a sensação provocada por uma mesma amostra. Esta ocorrência não é incomum e é difícil de ser evitada na análise sensorial.

Foi observado efeito das fontes de lipídeos $(P=0,01)$ sobre o sabor estranho na carne, sendo que o tratamento contendo caroço de algodão apresentou maior valor que os tratamentos com soja "in natura" e semente de girassol (Tabela 8). Já, em relação à fonte de Se na alimentação dos animais, no presente trabalho, os bovinos tratados com fonte inorgânica tiveram carnes com maiores valores para o atributo de sabor estranho, quando comparados àqueles alimentados com dietas com Se orgânico $(P=0,01)$. Resultados diferentes foram observados por Shibuya (2004), que verificou que a inclusão de gordura protegida, milho úmido ou caroço de 
algodão na dieta dos animais, alterou pouco ou nada a percepção dos consumidores sobre os atributos sensoriais testados. Pesce (2008) não verificou sabor estranho na carne de novilhos Nelore alimentados com duas concentrações diferentes de caroço de algodão (10\% e $20 \%$ da MS). Igualmente, Gibb et al. (2004), estudando fornecimento de semente de girassol a bovinos, não observaram diferença para sabor estranho no músculo Longissimus de bovinos quando comparados tratamentos contendo sementes de girassol na proporção de 10,8\% e 14\%.

O sabor da carne vermelha é derivado da reação de Maillard entre aminoácidos, redução dos açúcares e degradação térmica dos lipídeos. Desse modo, estratégias que alterem a composição de ácidos graxos da fração lipídica da carne podem também modificar a quantidade e o tipo volátil produzido e, portanto o aroma e sabor dos cortes cárneos (SCOLLAN et al., 2006).

Não foi observada diferença de fontes de lipídeos $(P=0,09)$ e de Se $(P=0,11)$ para o aroma característico. O aroma estranho também não diferiu no músculo Longissimus de bovinos recebendo diferentes fontes de lipídeo $(P=0,71)$ e fontes de Se $(P=0,74)$. Para textura da carne entre os tratamentos contendo fontes de lipídeos $(P=0,09)$ e de Se $(P=0,28)$, os resultados foram similares aos resultados encontrados quando a maciez foi avaliada por FC e para o IM das amostras de carne. Entretanto, a presença de marmorização na carne tem pequena influência na maciez da carne, variando entre 10 ou menor que 15\% (KOOHMARAIE et al., 2003).

Tabela 8 - Atributos sensoriais do músculo Longissimus

\begin{tabular}{|c|c|c|c|c|c|c|c|}
\hline \multirow[b]{2}{*}{ Características } & \multicolumn{2}{|c|}{ Fontes de lipídeos } & \multicolumn{5}{|c|}{ Fontes de selênio } \\
\hline & $\begin{array}{l}\text { Caroço } \\
\text { de } \\
\text { Algodão }\end{array}$ & $\begin{array}{c}\text { Semente } \\
\text { de } \\
\text { Girassol }\end{array}$ & $\begin{array}{l}\text { Soja "in } \\
\text { natura" }\end{array}$ & $P$ & Org. & Inorg. & $\mathrm{P}$ \\
\hline Sabor Estranho & $2,02^{a}$ & $1,48^{b}$ & $1,66^{b}$ & 0,01 & 1,54 & 1,91 & 0,01 \\
\hline $\begin{array}{l}\text { Aroma } \\
\text { Característico }\end{array}$ & 5,41 & 5,46 & 5,11 & 0,09 & 5,44 & 5,21 & 0,11 \\
\hline $\begin{array}{l}\text { Aroma } \\
\text { Estranho }\end{array}$ & 1,63 & 1,63 & 1,75 & 0,71 & 1,64 & 1,69 & 0,74 \\
\hline Textura & 5,43 & 5,20 & 4,83 & 0,09 & 5,27 & 5,03 & 0,28 \\
\hline Suculência & $5,38^{a}$ & $4,93^{b}$ & $4,63^{b c}$ & 0,01 & 4,86 & 5,08 & 0,22 \\
\hline
\end{tabular}


Contudo, ao comparar os valores médios da análise sensorial e FC, independente dos tratamentos, as carnes avaliadas pelo painel sensorial treinado foram consideradas moderadamente macias, com valores médios de 5,15.

As fontes de lipídeos influenciaram na suculência da carne $(P<0,01)$. Porém, não foram observadas diferenças em relação às fontes de Se $(P=0,22)$. Os animais que consumiram caroço de algodão na dieta apresentaram carnes mais suculentas, quando comparados às demais fontes. Entretanto, os tratamentos com semente de girassol ou soja "in natura" nas dietas não diferiram entre si. Como não houve diferença entre os tratamentos, para o IM das carnes $(P=0,94)$, quando comparadas às fontes de lipídeos e quando comparadas as fontes de $\mathrm{Se}(\mathrm{P}=0,81)$, esperava-se que para a suculência, o comportamento fosse semelhante, já que, segundo Strong (2004), a deposição de gordura intramuscular está diretamente relacionada à palatabilidade e suculência da carne. 


\section{CONCLUSÃO}

O desempenho (ganho médio diário, matéria seca ingerida e conversão alimentar) e as características de carcaça (rendimento de carcaça, área de olho de lombo, espessura de gordura subcutânea, índice de marmorização, perdas totais ao cozimento e maciez objetiva) não foram influenciados pelo tipo de fontes de lipídeos ou de selênio na dieta.

A fonte de Selênio orgânica resultou em maiores concentrações de Selênio no tecido muscular dos bovinos Nelore, quando comparado a fonte de Selênio Inorgânica.

As fontes de lipídeos utilizadas na dieta influenciaram o atributo de suculência e sabor estranho da carne dos animais estudados enquanto a fonte de selênio influenciou apenas no atributo de sabor estranho. 


\section{REFERÊNCIAS}

AFERRI, G.; LEME, P.R.; SILVA, S. L.; PUTRINO, S.M.; PEREIRA, A.S.C. Desempenho e características da carcaça de novilhos alimentados com dietas contendo diferentes fontes de gordura. Revista Brasileira de Zootecnia, v. 34, p. 1651-1658, 2005.

AGRIANUAL: Anuário da agricultura brasileira. São Paulo: FNP Consultoria e Comércio, 2007. p. 462-485,

AMMERMAN, C. B., H. L. CHAPMAN, G. W. BOUWMAN, J. P. FONTENOT, C. P. BAGLEY, AND A. L. MOXON. Effect of supplemental Se for beef cows on the performance and tissue Se concentrations of cows and suckling calves. Journal of Animal Science, v. 51, p. 1381-1386, 1980.

AMSA. American Meat Science Association. Research guidelines for cookery, sensory evaluation and instrumental tenderness measurements of fresh meat. Chicago, IL.: American Meat Science Association, 1995.

ANDRAE, J. G.; DUCKETT, S. K.; HUNT, C. W.; PRITCHARD, G. T.; OWENS, F. N. Effects of feeding high-oil corn to beef steers on carcass characteristics and meat quality. Journal of Animal Science, v. 79, p. 582-588, 2001.

ARBOITTE, M. Z.; RESTLE, J.; ALVES FILHO, D.C.; BRONDANI, I.L.; SILVA, J.H.S.; NORNBËRG, J.L.; KUSS, F. Desempenho em confinamento de novilhos 5/8 Nelore - 3/8 Charolês abatidos em diferentes estádios de desenvolvimento. Revista Brasileira de Zootecnia, v. 33, p. 947-977, 2004.

ARIELI, A. Whole conttonseed in dairy cattle feeding: a review. Animal Feed Science and Technology, v. 72, p. 97-110, 1998.

BARBER, K. A.; WILSON, L. L.; ZIEGLER, J. H.; LE VAN, P.J.; WATKINS, J.L. Charolais and Angus steers slaughtered at equal percentages of mature cow weight II. Empty body composition, energetic efficiency and comparison of compositionally similar body weights. Journal of Animal Science, v. 53, p. 898-906, 1981.

BARTLE, S. J.; PRESTON, R. L.; MILLER, M. F. Dietary energy source and density: Effects of roughage source roughage equivalent, tallow level, and steer type on feedlot performance and carcass characteristics. Journal of Animal Science, v. 72, p. 1943-1953, 1994.

BENBOUZA, H.; LOGNAY, G.; PALM, R.; BAUDOIN, JP.; MERGEAI, G. Crop ecology, management e quality: development of a visual method to quantify the gossypol content in cottonseeds. Crop Science, v. 42, p. 1937-1942, 2002.

BENDER, A. Meat and meat products in human nutrition in developing countries. FAO, Rome, Food and Nutrition Paper, v. 53, p. 1-91, 1992. 
BERAN, F. H. B.; SILVA, L. D. F.; RIBEIRO, E. L. A.; ROCHA, M.A.; EZEQUIEL, J.M.B.; CORREA, R.A.; CASTRO, V.S.; SILVA, K.C.F. Avaliação da digestibilidade de nutrientes, em bovinos, de alguns alimentos concentrados pela técnica de três estádios. Revista Brasileira de Zootecnia, v. 36, p. 130-137, 2007.

BERG, R. T.; BUTTERFIELD, R. M. Nuevos conceptos sobre desarrollo de ganado vacuno. Zaragoza: Acribia. 1979. 297 p.

BIANCHINI, W. Crescimento muscular e qualidade da carne de Bovinos nelore, simental e seus mestiços no sistema de produção superprecoce. 2005. 82 p. Dissertação (mestrado) - Faculdade de Medicina Veterinária e Zootecnia, UNESP, Botucatu, 2005.

BLOOD, D. C.; GAY, C. C.; RADOSTITS, O. M. Clínica veterinária: um tratado de doenças dos bovinos, ovinos, suínos, caprinos e eqüinos. 9. ed. Rio de Janeiro: Guanabara Koogan, 2002. 1770 p.

BRANDT JR., R. T.; ANDERSON, S. J. Use of supplemental fat to optimize net energy intake by feedlot cattle. In: INTAKE BY FEEDLOT CATTLE, 1995, Stillwater. Proceedings... Stillwater: Oklahoma State University, 1995. 942 p.

BRASIL. Ministério da Agricultura. Pecuária e Abastecimento. Regulamento da Inspeção Industrial e Sanitária de Produtos de Origem Animal. Brasília: Ministério da Agricultura, Pecuária e Abastecimento, 1997. 241 p.

BRASIL. Ministério da Saúde. Agência Nacional de Vigilância Sanitária. Resolução $n^{\circ} 482$, de 23 de setembro de 1999. Regulamento técnico para fixação de identidade e qualidade de óleos e gorduras vegetais. Diário Oficial da União, Brasília, 13, out,1999. Anexo 5.

BRONDANI, I. L.; SAMPAIO, A. A. M.; RESTLE, J.; FILHO, D. C. A.; FREITAS, L. S.; AMARAL, G. A.; SILVEIRA, M. F.; CEZIMBRA, I. M. Composição física da carcaça e aspectos qualitativos da carne de bovinos de diferentes raças, alimentados com diferentes níveis de energia. Revista Brasileira de Zootecnia, v. 35, p. 2034-2042, 2006.

BROSH, A.; HOLZER, Z.; LEVY, D. Cottonseed for protein and energy supplementation of highroughage diets for beef cattle. Animal Production, v. 48, p. 513-518, 1989.

BURTIS, C. A.; ASHWOOD, E. R. Fundamentals of clinical chemistry. 5. ed. Philadelphia: W. B. Company, USA, 2001.

BUTOLO, J. E. Qualidades de ingredientes na alimentação animal. Campinas: [s. n.], 2002. $430 \mathrm{p}$.

CARVALHO, S.; PIRES, C. C.; PERES, J. R. R. Predição da composição tecidual da carcaça de cordeiros. In: REUNIÃO ANUAL DA SOCIEDADE BRASILEIRA DE ZOOTECNIA, 35., 1998, Botucatu. Anais... Botucatu: falta editora, 1998. p.110-112. 1998. 
CASES, J.; PUIG, M.; CAPORICCIO, B.; BAROUX, B.; BACCOU, J. C.; BESANÇON, P.; ROUANET, J. M. Glutathione related enzymic activities in rats receiving hight cholesterol standart diets supplemented with two forms of selenium. Food Chemistry, v. 65, p. 207-211, 1999.

CAVASIN, P. A cultura do girassol. Guaíba: Agropecuária, 2001. 69 p.

CHILLIARD, Y. Dietary fat and adipose tissue metabolism in ruminants, pigs and rodents: a review. Journal of Dairy Science, v. 76, p. 3897-3931, 1993.

CLARY, E. M.; BRANDT JR, R. T.; HARMON, D. L.; NAGARAJA, T. G. Supplemental fat and ionophores in finishing diets: Feedlot performanceand ruminal digesta kinetics in steers. Journal of Animal Science, v. 71, p. 3115-3123, 1993.

COMBS, G. F.; LARK, B. W.; TURNBULL, B. W. An analysis of cancer prevention by selenium. Biofactors, v. 14, p. 153-159, 2001.

COPPOCK, C. E.; LANHAM, J. K.; HONNER, J. I. A review of the nutritive value and utilization of whole cottonseed, cottonseed meal and associated by products by dairy cattle. Animal Feed Science and Tecnology, v. 18, p. 89-120, 1987.

COPPOCK, C. E.; WILKS, D. L. Supplemental fat in high-energy rations for lactating cows: effect on intake, digestion, milk yield and composition. Journal of Animal Science, v. 69, p. 3826-3837, 1991.

CORTE, R. R. P. S.; LEME, P. R.; AFERRI, G.; PEREIRA, A. S. C.; SILVA, S. L. Meat characteristics of crossbred lambs fed normal or heated whole cottonseed. In: JOINT ADSA-ASAS ANNUAL MEETING, 2008, Indianápolis. [Proceedings...] 2008. p.151

CUNHA, M. G. G.; CARVALHO, F. F. R.; VÉRAS, A. S. C.; BATISTA, A. M. V. Desempenho e digestibilidade aparente em ovinos confinados alimentados com dietas contendo níveis crescentes de caroço de algodão integral. Revista Brasileira de Zootecnia, v.37, p.1103-1111, 2008.

DALLAGNOL, A.; VIEIRA, O. V.; LEITE, R. M. V. B. C. Origem e histórico do girassol. Girassol no Brasil. Londrina: CNPSO, 2005. p. 1-12.

DAMODARAN, S. Struture- function relationship of food protein. In: HETTIARACHCHY, N. S.; ZIEGLER, G. R. Protein functionality in food system. Marcel Dekker Inc., 1994. p.1-37.

DEL CLARO G. R. Influência da suplementação de cobre e selênio no metabolismo de lipídeos em bovinos. 2007. 89 p. Tese (Doutorado) - Faculdade de Zootecnia e Engenharia de Alimentos, Universidade de São Paulo, Pirassununga, 2007.

DEPETERS, E. J.; TAYLOR, S. J.; FRANKE, A. A.; Aguirre, A. Effects of feeding whole cottonseed on composition of milk. Journal of Dairy Science, v. 68, p. 897902, 1985. 
DEVENDRA, C.; LEWIS, D. The interaction between dietary lipids and fibre in the sheep. 2. Digestibility studies. Animal Production, v. 19, p. 67-76, 1974.

DRANSFIELD, E. Optimisation of tendernisation, ageing and tenderness. Meat Science, v. 36, p. 105-121, 1994.

DUARTE, L. M. D'A.; STUMPF JR, W.; FISCHER, V.; SALLA, L. E. Efeito de diferentes fontes de gordura na dieta de vacas jersey sobre o consumo, produção e composição do leite. Revista Brasileira de Zootecnia, v. 34, p. 2020-2028, 2005.

DUCKETT, S. K.; WAGNER, D. G.; YATES, L. D.; Dolezal, H. G.; May, G. Effects of time on feed on beef nutrient composition. Journal of Animal Science, v. 71, p. 2079-2085, 1993.

EKHOLM, P.; VARO, P.; ASPILA, P.; KOIVISTOINEN, P.; SYRJÄLÄ-QVIST, L. Transport of feed selenium to different tissues of bulls. British Journal of Nutrition, v. 66, p. 49-55, 1991.

ENSMINGER, M. E.; OLDFIELD, J. E.; HEINEMANN, W. W. Feeds and nutrition. Clovis, Ca: The Ensminger, 1990.

EZEQUIEL, J. M. B. Uso de caroço de algodão na alimentação animal. In.:SIMPÓSIO GOIANO SOBRE MANEJO E NUTRIÇÃO ANIMAL, 3., 2001. Goiânia, Anais... Goiânia: Colégio Brasileiro de Nutrição Animal, 2001. p. 307-328.

FAHMY, M. H.; BOUCHER, J. M.; POSTE, L. M.; GRÉGOIRE,R.; BUTLER,G.; COMEAU,J.E. Feed efficiency, carcass characteristcs, and sensory quality of lambs, with or without prolific ancestry, fed diets with different protein supplements. Journal of Animal Science, v. 70, p. 1365-1374, 1992.

FERNANDES, F. D. Uso da soja crua, soja tostada e soja crua/uréia como suplemento protéico para vacas em lactação. 1987. 80 p. Dissertação (Mestrado em Nutrição de Ruminantes) - Escola Superior de Agricultura de Lavras, Lavras, MG, 1987.

FRASER, A. F. (Ed.). Ethology of farm animals, a comprehensive study of the behavioural features of the common farm animals. New York: Elsevier, 1985. p. 183-200.

FRENCH, P.; STANTON, C.; LAWLESS, E. G.; O'RIORDAN, E. G.; MONAHAN, F. J.; CAFFREY, P. J.; MOLONEY, A. P. Fatty acid composition, including conjugated linoleic acid, of intramuscular fat from steers offered grazed grass silage, or concentrate-based diets. Journal of Animal Science, v. 78, p. 2849-2855, 2000.

GARCIA, W. R. Processamento da soja grão e do caroço de algodão em dietas de vacas leiteiras. 2005. 91 p. Tese (Doutorado em Zootecnia) - Universidade Federal de Lavras, Lavras, MG, 2005.

GEAY, Y.; BAUCHART, D.; HOCQUETTE, J.; CULIOLI, J. Effect of nutritional factors on biochemical, structural and metabolic characteristics of muscles in ruminants, consequences on dietetic value and sensorial qualities of meat.

Reproduction Nutrition Development, v. 41, p. 1-26, 2001. 
GESUALDI JR., A. G.; PAULINO, M. F.; VALADARES FILHO, S. C.; SILVA, J. F. C.; VELOSO, C. M.; CECON, P. R. Níveis de concentrado na dieta de novilhos F1 Limousin x Nelore: Características da carcaça. Revista Brasileira de Zootecnia, v. 29, n. 5, p. 1467-1473, 2000.

GIBB, D. J.; OWENS, F. N.; MIR, P. S. .; MCALLISTER, T.A. Value of sunflower seed in finishing diets of feedlot cattle. Journal of Animal Science, v. 82, p. 26792692, 2004.

GRAY, M. L.; GREENE, L. W.; WILLIAMS, G. L. Effects of dietary gossypol consumption on metabolic homeostasis and reproductive endocrine function in beef heifers and cows. Journal of Animal Science, v. 71, p. 3052-3059, 1993.

GRIS, C. F.; REZENDE, P. M.; CARVALHO, E. A.; BOTREL, E. P.; EVANGELISTA, A. R.; ANDRADE, M. J. B. Épocas de corte e cultivares na composição mineral de feno de soja [Glycine max (L.) Merrill]. Ciência e Agrotecnologia, v. 32, n.2 , p.413419, 2008.

GUNTER, S. A.; BECK, P. A.; PHILLIPS, J. M. Effects of supplementary selenium source on the performance and blood measurements in beef cows and their calves. Journal of Animal Science, v. 81, p. 856-864, 2003.

HAWKINS, E. G.; CUMMINS, K. A.; SILVÉRIO, O. M.; JSLEK, J. J. Physiological effects of whole cottonseed in the diet of lactating dairy cows. Journal of Dairy Science, v. 68, p. 2608-2614, 1985.

HENDERSON, C. The effects of fatty acids on pure cultures of rumen bacteria. Journal of Agricultural Science, v. 81, p. 107, 1973.

HOLBEN, D. H. The diverse role of selenium within selenoproteins: A review. Journal of American Diet Association, v. 99, p. 836-843, 1999.

HUERTA-LEIDENZ, N. O.; CROSS, H. R.; LUNT, D. K.; PELTON, L. S.; SAVELL, J. W.; SMITH, S. B. Growth, carcass traits, and fatty acid profiles of adipose tissues from steers fed whole cottonseed. Journal of Animal Science, v. 69, p. 3665-3672, 1991.

ITO, R. H. Desempenho e qualidade da carne de bovinos terminados em confinamento suplementados com óleo de soja e semente de linhaça . 2005. 63 p. Dissertação (mestrado) - Faculdade de Zootecnia, Universidade Estadual de Maringá, Maringá, 2005.

ITOH, M.; SUZUKI, K. T. Effects of dose on the methylation of selenium to monomethylselenol and trimethylselenonium ion in rats. Archives of Toxicology, $\mathrm{v}$. 71, p. 461- 827, 1997.

JENKINS, T. C. Lipid metabolism in the rumen. Journal of Dairy Science, v. 76, p. 3851-3863, 1993.

JONES, S. D. M.; ROMPALA, R. E.; JEREMIAH, L. E. Growth and composition of the empty body in steers of different maturity types fed concentrate or forage diets.

Journal of Animal Science, v. 60, p. 427-433, 1985. 
KANG, B. P. S.; BANSAL, M. P.; MEHATA, U. Hyperlipidemia and type I 5' monodeiodinase activity - Regulation by selenium supplementation in rabbits. Biological Trace Element Research, v. 77, p. 231-239, 2000a.

KANG, B. P. S.; BANSAL, M. P.; MEHATA, U. Hyperlipidemia and type I 5' monodeiodinase activity- Regulation by selenium supplementation. Indian Journal of Biochemistry \& Biophysics, v. 37, p. 183-187, 2000b.

KANG, B. P. S.; BANSAL, M. P.; MEHATA, U. Selenium supplementation and diet induced hypercholesterolemia in the rat: Changes in lipid levels. malanoyldialhyde production and the nitric oxide synthase activity. General Physiology and Biophysics, v. 17, p. 71-78, 1998.

KNAPP, D. M; GRUMMER, R. R.; DENTINE, M. R. The response of lactating dairy cows to increasing levels of roasted soybeans. Journal of Dairy Science, v. 74, p. 2563-2572, 1991.

KOENIG, K. M.; RODE, L. M.; COHEN, R. D. H.; BUCKLEY, W. T. Effects of diet and Chemical form of selenium on selenium metabolism in sheep. Journal of Animal Science, v. 75, p. 817-827, 1997.

KOOHMARAIE, M.; VEISETH, E.; KENT, M. P.; SHACKELFORD, S. D. Understanding and managing variation in meat tenderness. Santa Maria, Brasil. In: REUNIÃO ANUAL DA SOCIEDADE BRASILEIRA DE ZOOTECNIA, 40. 2003, Santa Maria/RS. Anais... 2003.

LANNA, D. P. D.; ALMEIDA, R.; NEPOMUCENO, N. BARIONI, L G ; BICUDO, J. E.P.W. ; CAIXETA, J.V.; HOFFMANN, B.M. RLM 3.0 - Ração de Lucro Máximo. Versão 3.0. 2005.

LAWLER, T.L.; TAYLOR, J. B.; FINLEY, J. W.; CATON, J. S. Effect of supranutritional and organically bond selenium on performance carcass characteristics, and selenium distribution in fishing beff steers. Journal of Animal Science, v. 82, p. 1488-1493, 2004.

LEHNINGER, A. L.; NELSON, D. L.; COX, M. M. The biosynthesis of lipids. In: LEHNINGER, .A.L. (Ed). Priciples of biochemistry. 3. ed. New York: Worth Publishers, 2000. p. 770-817.

LEVANDER, O. A. Selenium. In: Trace Elements in Human and Animal Nutrition, ed. 5, v.2, Academic Press, Inc. Harcourt Bracc Jovanovich Orlando-FL, p.209-279, 1986.

LIN, H.; BOYSLON, T. D.; CHANG, M. J.; LUEDECKE, L. O.; SHULTZ, T. D. Survey of the conjugated linoleic acid contents of dairy products. Journal of Dairy Science, v. 78, p. 2358-2365, 1995.

LIU, Q.; LANARI, C.; SCHAEFER, D. M. A review of dietary vitamin e supplementation for improvement of beef quality. Journal of Animal Science, v. 73, p. 3131-3140, 1995. 
LUBIS, D.; VAN HORN, H. H.; HARRIS, Jr, B.; BACHMANN, K. C.; EMANUELLE, S. $M$. Responses of lactating dairy cows to protected fats or whole cottonseed in low or high forrage diets. Journal of Animal Science, v. 73, p. 3512-3525, 1990.

LUCHIARI FILHO, A. Pecuária da carne bovina. 1.ed. São Paulo, 2000. 134p.

LUZ E SILVA, S.; LEME, P. R.; PUTRINO, S. M.; LANNA, D.P.D. Alterações nas características de carcaça de tourinhos Nelore, avaliadas por ultra-som. Revista Brasileira de Zootecnia, v. 35, p. 607-612, 2006.

MADRON, M. S.; PETERSON, D. G.; DWYER, D. A.; CORL, B. A.; BAUMGARD, L. H.; BEERMANN, D. H.; BAUMAN, D. E. Effect of extruded full-fat soybeans on conjugated linoleic acid content of intramuscular, intermuscular, and subcutaneous fat in beef steers. Journal of Animal Science, v. 80, p. 1135-1143, 2002.

MAHAN, D. C.; MOXON, A. L. Effects of Adding Inorganic or Organic Selenium Sources to the Diets of Young Swine. Jounal of Animal Science, v. 47, p. 456-466, 1978.

MANDARINO, G. M. J. Características bioquímicas e nutricionais do óleo e do farelo de girassol. Londrina, PR. Empresa Brasileira de Pesquisa AgropecuáriaEMBRAPA- Centro Nacional de Pesquisa de Soja -CNPSO, 1992.

MAY, S. G.; DOLEZAL, H. G.; GILL, D. R.; RAY, F. K.; BUCHANAN, D. S. Effects of days fed, carcass grade traits, and subcutaneous fat removal on post mortem muscle characteristics and beef palatability. Journal of Animal Science, v. 70, p. 444-453, 1992.

McDOWELL, L.R. Minerals in animal and human nutrition. New York: Academic Press, 1992.

MEAT EVALUATION HANDBOOK, 1973. National live stock and meat board. Chicago, 1973. $70 \mathrm{p}$.

MEDEIROS, G. R. Efeito de níveis de concentrado sobre o desempenho, característica de carcaça e componentes não carcaça de ovinos Morada Nova em confinamento. 2006. 108 p. 108p. Tese (Doutorado em Zootecnia) Universidade Federal Rural de Pernambuco, Recife, 2006.

MELO, A. A. S.; FERREIRA, M. A.; VÉRAS, A. S. C.; LIRA, M. A.; LIMA, L. E.; PESSOA, R. A. S.; BISPO, S. V.; CABRAL, A. M. D.; AZEVEDO, M. Desempenho leiteiro de vacas alimentadas com caroço de algodão em dieta à base de palma forrageira. Pesquisa Agropecuária Brasileira, Brasília, v. 41, p. 1165-1171, 2006.

MENEZES, L. F. G.; RESTLE, J.; BRONDANI, I. L.; CELESTINO, D. Características da carcaça de novilhos de gerações avançadas do cruzamento alternado entre as raças Charolês e Nelore terminados em confinamento. Revista Brasileira de Zootecnia, v. 34, p. 933-944, 2005. 
MILLER, R. K. Assessing consumer preferences and attitudes toward meat and meat products. In: International Congress of meat science and technology, 2, 2003, Campinas. Brazilian Journal of Food Technology, v. 6, p. 67-80, 2003. Special Tissue.

MILTON, C. T.; BRANDT, JR., R. T.; TITGEMEYER, E. C.; KUHL, G. L. Effect of degradable and escape protein and roughage type on performance and carcass characteristics of finishing yearling steers. Journal of Dairy Science, v. 75, p. 28342840, 1997.

MIR, P.S.; DUGAN, M.E.R.; HE, M.L.; ENTZ, T.; YIP, B. Effects of dietary sunflower seeds and tylosin phosphate on production parameters, carcass characteristics, fatty acid composition, and liver abscess incidence in crossbred steers. Journal of Animal Science, v. 10, p. 2527, 2008.

MOLETTA, J. L. Utilização de soja grão ou caroço de algodão, na terminação de bovinos de corte em confinamento. In: REUNIÃO ANUAL DA SOCIEDADE BRASILEIRA DE ZOOTECNIA, 36., 1999, Porto Alegre. Anais... São Paulo: Gnosis, 1999. 1 CD.

MORRISSEY, P. A.; SHEEHY, P. J. A.; GALVIN, K.; KERRY, J. P.; BUCKLEY, D. J. LIPID STABILITY IN MEAT AND MEAT PRODUCTS. Meat Science, v. 49, p.S73S86, 1998. Supplement, 1.

MULLER, M.; PRADO, I. N.; LOBO JÚNIOR, A. R.; SCOMPARIN, V. X.; RIGOLON, L.P. Diferentes fontes de lipídeos sobre o desempenho e características da carcaça de novilhas de corte confinadas. Animal Sciences, v. 27, p. 131-137, 2005.

NRC. NATIONAL RESEARCH COUNCIL. Mineral tolerance of animals. $2^{\text {th }} \mathrm{ed}$. Washington: National Academy Press, 2005.

NRC. NATIONAL RESEARCH COUNCIL. Nutrent requeriments of beef catle. $6^{\text {th }}$ ed. Washington : National Academy of Sciences, 1984. 90 p.

NRC. NATIONAL RESEARCH COUNCIL. Nutrient requirements of dairy cattle. $6^{\text {th }}$ ed. Washington: National Academic Press 1989. 157 p.

NRC. NATIONAL RESEARCH COUNCIL. Nutrient requirements of sheep. $6^{\text {th }}$ ed. Washington: National Academic Press, 1985. 99p.

NRC. NATIONAL RESEARCH COUNCIL. Nutrient requirements of swine. $9^{\text {th }}$ ed. Washington, DC : National Academy Press, 1988, 90 p.

NRC. NATIONAL RESEARCH COUNCIL. Selenium in Nutrition. National Academy Press, Washington, DC. National Academy Press, 1983

NRC. NATIONAL RESEARCH COUNCIL. Subcommittee on Dairy Cattle Nutrition. Nutrient requirements of dairy cattle. 7th ed. Washington: National Academy Press, 2001. 381p. 
O'GRADY, M.N.; MONAHAN, F.J.; FALLON, R.J.; ALLEN, P. Effects of dietary supplementation with vitamin $E$ and organic selenium on the oxidative stability of beef. Journal of Animal Science, v. 79, p. 2827-2834, 2001.

OWENS, F. N.; DUBESKI, P.; HANSON, C. F. Factors that alter the growth and development of ruminants. Journal of Animal Science, v. 71, p. 3138-3150, 1993.

PAGE, J. K.; STURDIVANT, C. A.; LUNT, D. K.; SMITH, S. B. Dietary whole cottonseed depress lipogenesis but has no effect on stearoyl coenzyme desaturase activity in bovine subcutaneous adipose tissue. Comparative Biochemistry And Physiology, v. 118, p. 79-84, 1997.

PAIVA, F. A.; ZANETTI, M. A.; MARTINS, F. R.; CORREA, L. B.; CLARO, G. R.; NETO, A. S. Selenium metabolism in lambs supplied with different selenium sources and levels. In: INTERNATIONAL SCIENTIFIC SYMPOSIUM ON TRACE ELEMENTS IN ANIMAL PRODUCTION SYSTEMS, 1., 2007, Genebra. Proceedings... Genebra, 2007.

PALMQUIST, D. L. Influence of source and amount of dietary fat on digestibility in lacting cows. Journal of Dairy Science, v. 74, p. 1351-1360, 1991.

PALMQUIST, D. L. Ruminal and endogenous synthesis of CLA in cows. Australian Journal of Dairy Technology, v. 56, p. 134-137, 2001.

PALMQUIST, D. L.; JENKINS, T. C. Fat in lactation rations: review. Journal of Dairy Science, v. 63, p. 1-14, 1980.

PALMQUIST, D. L.; MATTOS, W. Turnover of lipoproteins and transfer to milk fat dietary (1-carbon-14) linoleic acid in lactating cows. Journal of Dairy Science, v. 61, p. 561-565, 1978.

PAPAS, A. M. Determinants of antioxidant status in humans. Lipids, v. 31, p. S77S82, 1996. Supplement.

PARDI, M. C.; SANTOS, I. F.; SOUZA, E. R.; PARDI, H.S. Ciência e tecnologia da carne. Goiânia: CEGRAF-UFG, 1995. v.1, 586 p.

PASCHOAL, J. J.; ZANETTI, M. A.; DEL CLARO, G. R.; MELO, M. P.; PUGINE, SW. P.; CUNHA, J. A. Fatty acid profile and oxidative stability of milk from Holstein cows fed with extruded soybean and organic selenium. Pesquisa Agropecuária Brasileira, v. 42, p. 1793-1799, 2007.

PAULINO, M.F.; DETMANN, E.; VALADARES FILHO, S.C.; LANNA, R.P. Soja grão e caroço de algodão em suplementos múltiplos para a terminação de bovinos mestiços em pastejo. Revista Brasileira de Zootecnia, v. 31, p. 484-491, 2002.

PAVLATA, I.; ILLEK, J.; PECHOVÁ, A. Blood and tissue selenium concentration in calves treated with inorganic or organic selenium compounds - a comparison. Acta Veterinaria Brno, v. 70, p. 19-26, 2001. 
PELEGRINI, L. F. V. de; PIRES, C. C.; RESTLE, J. Efeitos de duas fontes protéicas sobre o desempenho de terneiros confinados. Ciência Rural, Santa Maria, v. 30, p. 475-479, 2000.

PESCE, D. M. C. Efeito da dieta contendo caroço de algodão no desempenho, características quantitativas da carcaça e qualitativas da carne de novilhos Nelore confinados. 2008. 139 p. Tese (doutorado) - Faculdade de Zootecnia e Engenharia de Alimentos, FZEA-USP, Pirassununga, 2008.

PLATER, W. J. ; TATUM, J. D. ; BELK, K. E. ; CHAPMAN, P. L. ; SCANGA, J. A. ; SMITH, G. C. Relationships of consumer sensory ratings, marbling score, and shear force value to consumer acceptance of beef striploin steaks. Journal of Animal Science, v. 81, p. 2741-2750, 2003.

POPINIGIS, F. Fisiologia da semente. Brasília: Editora Pax, 1985. 289 p.

PRADO, I. N.; BRANCO, A. F.; ZEOULA, L. M.; PINTO, A. A.; MORAES, G. V.; MOREIRA, H. L. M. Desempenho e características de carcaça de bovinos Nelore confinados, recebendo 15 ou 30\% de caroço integral de algodão, bagaço autohidrolisado de cana-de-açúcar ou capim elefante. Arquivos de Biologia e Tecnologia. v. 38, p. 353-365, 1995.

RABELLO, T. G.; VALADARES FILHO, S. C.; SILVA, J. F. C.; LEÃO, M. I.; CECON, P. R.; CASTRO, A. C. G. Grão de soja moído na alimentação de vacas em lactação I. Consumos, produção e composição do leite. Revista da Sociedade Brasileira de Zootecnia, v. 25,p. 345-356, 1996.

RAYMAN, M. P. The importance of selenium to human health, review, The Lancet, v. 356, p. 233-241, 2000.

REDDY, P. V.; MORRIL, J. L.; NAGARAJA, T. G. Release of fatty acids from raw or processed soybeans and subsequent effects on fiber digestibilities. Journal of Dairy Science, v. 77, p. 341-346, 1994.

RICHARDSON, C. R.; BEVILLE, R. N.; RATCLIFF, R. K.; ALBIN, R.C. Sunflower as a protein supplement for growing ruminants. Journal of Animal Science, v. 53, p. 557-63, 1981.

ROGÉRIO, M.C.P.; BORGES, I.; TEIXEIRA, D.A.B.; RODRIGUEZ, N.M. GONÇALVES, L.C. Efeito do nível de caroço de algodão sobre a digestibilidade da fibra dietética do feno de Tifton 85 (Cynodon spp.) em ovinos. Arquivo Brasileiro Medicina Veterinária Zootecnia, v. 56, p. 665-670, 2004.

RUEGSEGGER, G. J.; SCHULTZ, L. H. Response of high production dairy cows in earty lactation to the feeding of heattreated whole soybeans. Journal of Dairy Science, v. 68, p. 3272-3279, 1985.

SALDANHA, T.; MAZALLI, M. R.; BRAGAGNOLO, N. Avaliação comparativa entre dois métodos para determinação do colesterol em carnes e leite. Ciência e Tecnologia de Alimentos, v. 24, p. 109-113, 2004. 
SALLA, L. E.; FISCHER, V.; FERREIRA, E. X.; MORENO, C. B.; JUNIOR, W. S.; DUARTE, L. D. Comportamento Ingestivo de Vacas Jersey Alimentadas com Dietas Contendo Diferentes Fontes de Gordura nos Primeiros 100 Dias de Lactação, Revista Brasileira de Zootecnia, v. 32, p. 683-689, 2003.

SAS. STATISTICAL ANALISYS SYSTEM. User's guide: basic and statistic. Cary: SAS, 1995. $1686 \mathrm{p}$.

SCHWARZ, K.; FOLTZ, C. M. Selenium as an integral part of Factor 3 against dietary necrotic liver degeneration. Journal of Am. Chemistry Soc., v. 79, p. 3292-3293, 1957.

SCOLLAN, N.; HOCQUETTE, J. F.; NUERNBERG, K.; DANNENBERGER, D.; RICHARDSON, I.; MOLONEY, A. Innovations in beef production systems that enhance the nutritional and health value of beef lipids and their relationship with meat quality. Meat Science. v. 74, p. 17-33. 2006.

SHIBUYA, C. M. Análise sensorial da carne (m.L.dorsi )de novilhos terminados com dietas de milho seco vs. amido, com ou sem gordura protegida (Lactoplus)e de Lactoplus vs. caroço de algodão. 2004. 78 p. Tese. (doutorado). - Universidade Estadual de Campinas, Faculdade de Engenharia de Alimentos, Campinas, 2004.

SILVA, D. J. Análise de alimentos: métodos químicos e biológicos. Viçosa, MG: Universidade Federal de Viçosa, 1998.

SILVA, M. N. A cultura do girassol. Jaboticabal: FUNEP, 1990. 67 p.

SMITH, N. E.; COLLAR, L. S.; BATH, D. L. Whole cottonseed and extrused soybean for cows in earty lactating. Journal of Dairy Science, v. 63, p. 153, 1980.

STAKE, P. E.; OWENS, M. J.; SCHINGOETHE, P. J. Rapeseed, sunflower and soybean meal supple- mentation of calf rations. Journal of Dairy Science, v. 56, p. $783,1973$.

STERN, M. D.; ILLG, D. J. Empleo de soya integral e la alimentación de ruminantes. Soya Noticias, v. 20, p. 277-14-20, 1991.

STRONG, J. Differences in carcass grading schemes used in the USA, Japan and Austrália. Australian Journal of Experimental Agriculture, v. 44, p. 675-680, 2004.

SURAI, P. F. Selenium in Nutrition and Health. United Kingdom: Nottingham University Press, 2006.

SURAI, P.F.; SPEAKE, B.K.; NOBLE, R.C. et al. Tissue-specific antioxidant profiles and susceptibility to lipid peroxidation of the newly hatched chick. Biology Trace Element Research, v.68, p.63-78, 1999.

TAUBES, G. The soft science of dietary fat. Science, v. 291, p. 2536-2541, 2001. 
TEIXEIRA, J. C.; HUBER, J. T. Determinação da digestibilidade pós ruminal da proteína de caroços de algodão pela técnica do saco de nylon móvel em vacas leiteiras. Revista da Sociedade Brasileira de Zootecnia, v.18, p.295, 1989.

ULLREY, D. E.; BRADY, P. S.; WHETTER, P. A. et al. Se, supplementation of diets for sheep and beef cattle. Journal of Animal Science, v. 46, p. 559-565, 1977.

URANO, F. S. Grão de soja na alimentação de cordeiros: desempenho, características da carcaça e digestibilidade dos nutrientes. 2005. 63 p. Dissertação (Mestrado) - Escola Superior de Agricultura Luiz de Queirós, Universidade de São Paulo, Piracicaba, 2005.

USDA. Official United States standards for grades of carcass beef. Washington, D.C.,: Agricultural Marketting Serv., USDA, 1999.

VALINOTE, A. C.; NOGUEIRA FILHO, J. C. M.:, LEME, P. R.; LUZ E SILVA, S.; J.; CUNHA, J. A. Fontes de Lipídeos e Monensina na Alimentação de Novilhos Nelore e sua relação com a População de Protozoários Ciliados do Rúmen. Revista Brasileira de Zootecnia, v. 34, p. 1418-1423, 2005.

VARGAS, L. H.; LANA, R. P.; JHAM, G. N. Adição de lipídeos na ração de vacas leiteiras: parâmetros fermentativos ruminais, produção e composição do leite.

Revista Brasileira de Zootecnia, v. 31, p. 522-529, 2002.

VINCENT, I. C.; HILL, R.; CAMPLING, R. C. A note on the use of rapeseed, sunflower and soya-bean meals as protein sources in compound foods for milking cattle. Animal Production, v. 50, n. 3, p. 541-543, 1990.

WHEELER, T. L.; SHACKELFORD, S. D.; KOOHMARAIE, M. Shear force procedures for meat tenderness measurement. Roman L. Hruska U.S. Meat Animal Research Center, USDA, Clay Center, NE, 2001.

WHEELER, T. L.; SHACKELFORD, S. D.; KOOHMARAIE, M. The accuracy and repeatability of untrained laboratory consumer panelists in detecting differences in beef longissimus tenderness. Journal Animal Science, v. 82, p. 557-562, 2004.

WILKS, D. L.; COPPOCK, C. E.; BROOKS, K. N. Effects of diferences in starch content of diets with whole cottonseed or rice bran on milk casein. Journal of Dairy Science, v. 74,p. 1314-1320, 1991.

YANG, A.;LARSTEN,T.W.;SMITH,S.B.;TUME,R.K. Delta 9 desaturase activity in bovine subcutaneous adipose tissue of different fatty acid composition. Lipids, v. 34, p. 971-978,1999.

ZINN, R. A. Comparative feeding value of supplemental fat in steam-flaked corn and steam flaked wheat based finishing diets for feedlot steers. Journal of Animal Science, v. 70, p. 2959-2969, 1992.

ZINN, R. A. Influence of level and source of dietary fat on its comparative feeding value in finishing diets for steers: feedlot cattle growth and performance. Journal of Animal Science, v. 67, p. 1029-1037, 1989. 
ZINN, R. A.; GULATI, S. K.; PLASCENCIA, A.; SALINAS, J. Influence of ruminal biohydrogenation on the feeding value of fat in finishing diets for feedlot cattle. Journal of Animal Sciences, v. 78, p. 1738-1746, 2000.

ZINN, R. A.; PLASCENCIA, A. Effects of forage level on the comparative feeding value of supplemental fat in growing-finishing diets for feedlot cattle. Journal of Animal Science, v. 74, p. 1194-1201, 1996. 
ANEXO

\title{
Anexo A
}

\section{ANÁLISE SENSORIAL DE CARNE BOVINA}

Nome:

Data:

Laboratório:

Ramal:

Você recebeu uma amostra de carne bovina. Por favor, prove a amostra e dê uma nota a cada atributo de acordo com as escalas correspondentes.

Amostra

\author{
Aroma característico ( ) \\ 8- Extremamente forte \\ 7 - Muito forte \\ 6 - Forte \\ 5 - Moderado \\ 4 - Fraco \\ 3-Muito fraco \\ 2 - Extremamente fraco \\ 1 - Ausente \\ Aroma estranho ( ) \\ 8 - Extremamente forte \\ 7 - Muito forte \\ 6 - Forte \\ 5 - Moderado \\ 4-Fraco \\ 3-Muito fraco \\ 2 - Extremamente fraco \\ 1 - Ausente
}

Textura ( )

8 - Extremamente macia

7 - Muito macia

6 - Moderadamente macia

5 - Levemente macia

4 - Levemente dura

3-Moderadamente dura

2 - Muito dura

1 - Extremamente dura

Suculência ( )

8 - Extremamente suculenta

7 - Muito suculenta

6 - Moderadamente suculenta

5 - Levemente suculenta

4 - Levemente seca

3 - Moderadamente seca

2 - Muito seca

1 - Extremamente seca
Sabor característico ( )

8 - Extremamente forte

7 - Muito forte

6 - Forte

5 - Moderado

4-Fraco

3-Muito fraco

2 - Extremamente fraco

1 - Ausente

Sabor estranho ( )

8 - Extremamente forte

7 - Muito forte

6 - Forte

5 - Moderado

4 - Fraco

3 - Muito fraco

2 - Extremamente fraco

1 - Ausente

Comentários: 